\title{
Corporate social responsibility and bank risk
}

\author{
Florian Neitzert ${ }^{1} \cdot$ Matthias Petras $^{1}$
}

Accepted: 27 October 2021 / Published online: 11 November 2021

(c) The Author(s) 2021

\begin{abstract}
The concept of sustainable banking has developed significantly in recent years. Previous research found that corporate social responsibility reduces firm risk, yet this empirical evidence refers almost exclusively to non-financial companies and it remains unclear whether the risk-mitigating effect stems from the environmental, social, or governance pillar. The paper aims to analyse the impact of corporate social responsibility activities on bank risk and to explore its determinants. Using a sample of 582 banks worldwide over the period from 2002 to 2018, we confirm a riskreducing effect of the corporate social responsibility activity on an aggregated level. The decomposition of this effect suggests that environmental activities determine this risk mitigation. In contrast, social and governance activities do not show similarly unambiguous results. In this way, our analysis highlights the great importance of environmental aspects in banks' risk management.
\end{abstract}

Keywords Bank risk · Default risk · Portfolio risk $\cdot$ Sustainability risk $\cdot$ CSR $\cdot$ ESG

JEL Classification G21 - G32 - M14 - Q56

\section{Introduction}

Sustainability has become one of the most pressing issues for society (United Nations 2015). Movements such as 'Fridays for Future' have recently contributed to the publicly perceived relevance of this topic in the context of climate change. However, the actual meaning of the term 'sustainability' remains unclear. A widely recognised definition of sustainability is a broad understanding of the term, one that is not only limited to ecological issues. For companies, sustainability is often

Florian Neitzert

neitzert@wiso.uni-koeln.de

$\triangle$ Matthias Petras

petras@wiso.uni-koeln.de

1 Department of Bank Management, University of Cologne, Albertus-Magnus-Platz, 50923 Cologne, Germany 
operationalised as their corporate social responsibility (CSR), which is a management concept that integrates environmental, social, and ethical aspects of business operations into decision-making processes (Sassen et al. 2016). Companies' CSR activities can be assessed on the basis of scores for environmental, social, and governance (ESG) performance (Chollet and Sandwidi 2018; Nofsinger et al. 2019).

Aside from companies' responsibility to society, integrating ESG aspects into business activities can be seen as a form of risk management, whereby companies can reduce their vulnerability to sustainability risks and related financial risks. Due to its distinctive financial intermediation role, the banking industry is particularly exposed to sustainability risks. Banks are not only affected by ESG risks as companies themselves but also by the ESG risks of their clients (Bank of England 2018; EBA 2020). These risks are also reflected in banks' traditional risk categories. In terms of environmental aspects, physical climate risks (e.g. extreme weather events) are comparatively negligible for banks, whereas transitory risks are of utmost interest. For instance, the intended transition to a resource-efficient circular economy provides well-established industries (e.g. brown coal industry) with an uncertain future. As a result, bank financing for these industries is exposed to inherent credit and market price risks ('stranded assets'). Furthermore, neglecting social and ethical standards bears the risk of reputational damage, fines, and consequently higher probabilities of default. Also, well-functioning governance structures ensure suitable business conduct. Risk management theory indicates that CSR activities have a riskreducing effect (e.g. Godfrey et al. 2009; Bouslah et al. 2013; Sassen et al. 2016).

Empirical evidence for non-financial companies shows a negative relationship between CSR and firm risk (i.a. Sharfman and Fernando 2008; Jo and Na 2012; Bouslah et al. 2018). At the same time, especially for banks, the interdependencies of CSR and risk have been sparsely investigated so far (Gangi et al. 2019). Focussing on banks is relevant, however, because the financial system plays a pivotal role in the economic transformation process to a resource-efficient economy. Financial institutions provide the economy with capital and thus foster long-term economic growth (King and Levine 1993; Levine and Zervos 1998; Beck and Levine 2004). In this way, financial institutions are essential for the transformation process. What remains unclear is why risk is reduced and what determines the risk reduction.

We address these research gaps by analysing the effects of CSR activities on bank risk in detail. Our study is based on a data set of 582 banks from 2002 to 2018 . We use Thomson Reuters' ESG scores to measure banks' CSR, and the granular data enable us to analyse the effects at different levels. Bank-specific characteristics are addressed by using different accounting-based risk measures. In detail, we quantify a bank's default risk as well as its portfolio risk. Our analysis indicates a statistically significant risk-reducing effect for the overall CSR comprising all three pillars. Further, we conduct an in-depth analysis of the relationship between CSR and bank risk by separating CSR into three pillars (ESG) and ten sub-components. By doing so, we provide empirical evidence that the environmental pillar significantly determines the risk reduction. Analysing the effect of the environmental pillar in more detail yields that also individually, all sub-components of the environmental pillar (Environmental Innovation, Emissions, and Resource Use) reduce bank risk. In contrast, the findings for the social and governance pillar are equivocal. Therefore, 
we conclude that environmental engagement (rather than all three CSR dimensions) influences bank risk. Our results are robust to different model specifications, variable definitions, and winsorisation levels. By analysing the effects of CSR on bank risk in detail, we respond to the suggestions of Gramlich and Finster (2013) by providing specific evidence for the banking sector. In this way, we generate novel insights and contribute to both the strand of bank-specific CSR literature (e.g. Wu and Shen 2013; Cornett et al. 2016; Finger et al. 2018) and the literature on CSR and firm risk in general (e.g. Oikonomou et al. 2012; Gramlich and Finster 2013; Sassen et al. 2016; Albuquerque et al. 2018).

The rest of the paper is structured as follows. The subsequent section presents bank-specific CSR literature, enabling us to highlight that the relationship between CSR and bank risk has been a blank spot on the research map so far. Based thereon, we elaborate on the relevant theory to explain the connection between CSR and bank risk. Consequently, we develop our research hypotheses. Section 3 provides a summary of the sample, the dataset, and the methodology applied, while Sect. 4 presents the results. The findings of several robustness checks are presented in Sect. 5. Section 6 summarises the main insights and aspects of further research areas.

\section{Literature and hypotheses}

\subsection{Bank related literature}

In times of globalisation and climate change, CSR attracts increasing public interest. However, the term CSR is not universally defined. ${ }^{1}$ According to the United Nations, CSR is a "management concept whereby companies integrate social and environmental concerns in their business operations and interactions with their stakeholders. CSR is generally understood as being the way through which a company achieves a balance of economic, environmental, and social imperatives ('Triple-Bottom-Line-Approach'), while at the same time addressing the expectations of shareholders and stakeholders." (United Nations Industrial Development Organization 2020).

For banks, CSR is even more important, first, because of their specific business activities and, second, due to the loss of confidence in the wake of the global financial crisis in 2007 (Nandy and Lodh 2012; Marie Lauesen 2013; Hurley et al. 2014). In contrast to the manufacturing industry, banks primarily offer services (i.e., intangible products). Given the fact that the majority of clients have limited financial literacy, banks' reputation and trust are valuable assets (Soana 2011). The grievances that emerged more than 10 years ago in the wake of the financial crisis play a crucial role in this context. During that period, governments around the world rescued banks from bankruptcy with taxpayers' money to avert further negative effects on the financial stability, the real economy, and the society (Bayazitova and Shivdasani

\footnotetext{
1 Related concepts such as e.g. corporate sustainability, corporate social performance, or social performance are subsumed under the term CSR.
} 
2012; Iannotta et al. 2013; Hryckiewicz 2014). In this light, the business practices of banks with an intention of short-term profit maximisation were at the center of criticism (Wu and Shen 2013). Nevertheless, even in the post-crisis years, large capital market-oriented banks attracted attention again due to scandals such as the Libor manipulation (Fouquau and Spieser 2015; Köster and Pelster 2017). Altogether, this resulted in a historical loss of reputation for and trust in the banking sector (EstebanSanchez et al. 2017). For these reasons, there is a particular public interest in banks' CSR.

CSR is also a 'hot topic' in scientific research. A large number of studies have examined the manifold facets and implications of CSR for non-financial companies (Orlitzky and Benjamin 2001; Margolis et al. 2007; Friede et al. 2015), yet metaand survey studies state that research on CSR in the financial sector is comparatively rare (Goyal et al. 2013; Gramlich and Finster 2013; Wang et al. 2016). The majority of these bank-specific CSR studies focus on financial performance. ${ }^{2} \mathrm{Wu}$ and Shen (2013) examine the impact of CSR on banks' financial performance as well as the deeper motives of the underlying CSR engagement. Based on the bank profit function, which reflects both costs and possible benefits of CSR, they find a positive influence on banks' financial performance. In this context, strategic motives are seen as the primary driving force behind banks' commitment to CSR, whereas CSR activities motivated by greenwashing or altruistic motives generate costs that are not offset by additional financial benefits. In line with these findings, Shen et al. (2016) report empirical evidence that CSR increases the financial performance of banks worldwide. Taking up this research, Cornett et al. (2016) analyse the CSR effects on financial performance for banks around the financial crisis (2007) and report also a significant positive effect on financial performance. Their results are robust to different CSR definitions and performance measures. According to Scholtens and Dam (2007), the financial performance of banks that apply the Equator Principles ${ }^{3}$ does not differ significantly from that of non-adopters. Finger et al. (2018) study the effects of the adoption of the Equator Principles on banks' financial performance in industrialised and developing countries, finding no significant improvement in financial performance for banks in developed countries in the short and medium term, but observe a decline in financial performance in the long run for banks in developing countries. In addition, Chen et al. (2018) demonstrate that banks adopting the Equator Principles are stronger in terms of liquidity than non-applying banks.

Aside from the manifold literature on financial performance, from a risk perspective, only Gangi et al. (2019) postulate that banks' insolvency risk decreases as a consequence of their environmental commitment. Obviously, the effects of CSR on bank risk have so far been only sparsely investigated.

\footnotetext{
${ }^{2}$ Financial performance can be measured in different ways. For example, return on assets, return on equity, net interest income, and non-interest income are widely used as indicators of banks' financial performance.

3 The Equator Principles is a voluntary risk management framework that establishes a commitment of banks to integrate environmental and social aspects into project finance decisions. Since the first application in 2003, almost 100 financial institutions have implemented the Equator Principles.
} 


\subsection{Theoretical framework and hypotheses}

The relation of CSR and firm risk ${ }^{4}$ builds on theory and empirical evidence. From a conceptual point of view, risk management theory provides a framework that suggests the risk-reducing effects of CSR. In general, risk management includes actions like the identification, measurement, control, and mitigation of risks related to business activities. CSR comprises the management of ecological, social, and ethical aspects and influences firm risk in this way (Bouslah et al. 2013; Vishwanathan et al. 2019).

Given its increasing importance, central banks, the European Commission, and supervisory authorities have continuously called for better integration of sustainability risks ${ }^{5}$ in financial institutions' risk management (European Commission 2018; Bank of England 2018; EBA 2019). In the environmental context, most evident are the numerous risks related to climate change that occur in the transition to a resource-efficient circular economy. This risk category can be subdivided into 'environment-related' risks and 'climate-related' risks. The former category is defined as risks arising from environmental degradation such as pollution, water scarcity, or land contamination, whereas the latter includes physical risks (e.g. extreme weather events) and transitory risks (i.e. policy and legal risks or regulatory changes) (NGFS 2019). Because of banks' intermediary function, climate-related risks represent additional financial risks. Some examples of transitory risks that affect the traditional bank risk categories would be new political requirements for the transition from brown to green business, the ongoing technological progress, or changes in customer preferences. All of them are associated with potential disruptions that threaten the existence of established technologies and business models (e.g. the replacement of the combustion engine ('brown' business models)) (TCFD 2017; Mies and Menk 2019). In extreme cases, investments or entire industries lose their earning capacity before the end of their useful life and become 'stranded assets' (e.g. nuclear power plants) (NGFS 2019). This jeopardises the loan repayment ability of borrowers (credit risk channel). To cope with the additional credit and market price risks, banks can integrate voluntary guidelines (e.g. the Equator Principles, which ensure a closer consideration of sustainability aspects) in their lending practices, adjusting the risk exposures on the balance sheet. Complementary to this, natural disasters like the flooding of branches pose an operational risk in the banking context. Moreover, a massive outflow of customer deposits as a consequence of such environmental catastrophes represents an inherent liquidity risk (Bank of England 2018; BaFin 2020). Banks should be aware of such risks and establish a suitable risk provision.

Besides that, banking yields a social risk dimension as well, involving banks' interaction with employees and customers as well as the social perception of their business activities. Further, banks have to balance the pursuit of profitability with

\footnotetext{
${ }^{4}$ The term 'firm risk' is generally defined as "risk inherent in a firm's operations as a result of external or internal factors that can affect a firm's profitability" (Jo and Na 2012).

5 The term 'sustainability risks' comprises the ESG aspects equally.
} 
the preservation of ethical aspects (e.g. anti-money laundering, prevention of corruption and terrorism financing, and tax compliance). Specific actions could be the rejection of funding for disreputable sectors such as the arms industry or companies that violate labour and human rights standards, as well as the protection of highly sensitive customer data.

The financial crisis of 2007 was an important reminder of the necessity of functioning governance structures (Laeven and Levine 2009; Srivastav and Hagendorff 2016). For example, the misbehavior of traders like Kweku Adoboli (UBS) or Jérôme Kerviel (Société Générale) resulted in the loss of billions of euros for their respective banks (Rafeld et al. 2019). In this way, individual employees can constitute an operational as well as reputational risk. By the adaptation of business ethics policies (like the UN Principles for Responsible Banking), banks could reduce product and business ethics controversies and mitigate the risk of lawsuits and compensation payments (Bouslah et al. 2018). Beyond this, effective governance structures also comprise clear cut responsibilities and proper compensation models, in a sense to minimise the incentives for misconduct by individual employees, constituting operational as well as reputational risk. Also, for the integration of ESG factors into the bank's daily business, effective governance structures are essential (EBA 2020).

The examples described above highlight the theoretical relation of bank risk and CSR-related actions. Besides banking, research on non-financial companies has found that higher CSR is associated with lower financial risk (Orlitzky and Benjamin 2001). Likewise, Luo and Bhattacharya (2009) find empirical evidence for the risk management hypothesis and confirm a negative relationship between CSR and firm risk. Moreover, CSR creates moral capital and goodwill. Particularly in times of crisis, moral capital acts as a protection mechanism and alleviates the negative feedback effects of external events (Godfrey et al. 2009). In sum, risk management theory indicates that banks anticipate risk at an early stage. Consequently, CSR reduces a bank's vulnerability to financial, operating, environmental, and social risks (McGuire et al. 1988; Feldman et al. 1997; Sharfman and Fernando 2008).

Based on risk management theory and the empirical evidence for non-financial companies, in Hypothesis 1 we assume that CSR and bank risk are related as follows:

\section{H1: Overall CSR reduces bank risk.}

Bank risk interacts differently with the various CSR elements, and so a more granular analysis is warranted (Bouslah et al. 2013; Girerd-Potin et al. 2014; Chollet and Sandwidi 2018). Specifically, this includes the effects of the single CSR pillars (ESG) and the sub-components the three pillars consist of.

As previously described, environmental aspects are associated with bank risk. The environmental pillar is determined by the usage of exhaustible resources, the release of emissions in the business process, and an innovative and sustainable product portfolio. For instance, banks can link their lending practices to environmental criteria. Following risk management theory, a restrictive and selective lending process reduces banks' credit and portfolio risk (Nandy and Lodh 2012). A lower portfolio risk also implies a lower default risk of the bank, because of more stable income streams. By adjusting the bank's portfolio early to future environmental 
expectations by law-makers and society, banks can anticipate future needs for adjustment and pre-empt associated costs.

Social aspects are similarly relevant. Components of the social pillar such as working conditions or qualification measures indicate the quality of the bank's endeavors to promote and appreciate its employees and society. Because banking is a servicing business and therefore reliant on good relationships with the workforce and customers, the social performance can have direct implications for the bank's portfolio management performance and risk. As an expression of social responsibility, banks in the United States deferred interest and principal payments for affected borrowers in the aftermath of Hurricane Sandy (BusinessWire 2012). Similar to environmental engagement, and in line with risk management theory, banks can prevent costly controversies by ensuring social principles in business practice.

Besides, governance practices are seen as particularly important in the context of bank risk (John et al. 2008). The governance pillar comprises effective management, efficient and transparent decision-making processes, and the involvement of shareholders. Management and shareholders are key actors in the implementation of a sustainability philosophy and strategy. Therefore, consistent with risk management theory, we expect banks with good governance to be less failure-prone and behave in a more disciplined manner concerning their business practices (e.g. portfolio composition and individual misbehavior).

In sum, this raises the following hypothesis:

H2: Each single CSR-pillar (environmental-social-governance) has a reducing effect on bank risk.

\section{Empirical approach}

\subsection{Sample and data}

We perform an empirical analysis in order to test the hypotheses stated above. Our initial sample consists of 2452 banks worldwide, provided by Thomson Reuters' Eikon for the TRBC-sector 'Banking Services'. In total, the sample comprises banks from 115 countries around the world, with nearly a third headquartered in the United States. From the same data source, we collected fundamental data as well as ESG scores on an annual level.

ESG scores are used to quantify banks' CSR. The Thomson Reuters ESG database offers data on 400 different ESG metrics for more than 7000 companies worldwide, including banks, since 2002. The overall ESG score-indicating the total ESG performance-is composed of three pillars (Environmental-Social-Governance), respectively ten sub-components. The composition of the ESG score is illustrated in Fig. 1. In contrast to the methodology used for the previous product ASSET 4, the pillars and sub-components are not equally weighted. Instead, their weights depend on the number of available metrics to calculate each sub-component. In total, 178 metrics are considered to calculate the overall ESG score. Because only eight metrics are available for Human Rights and CSR-strategy, these sub-components have 


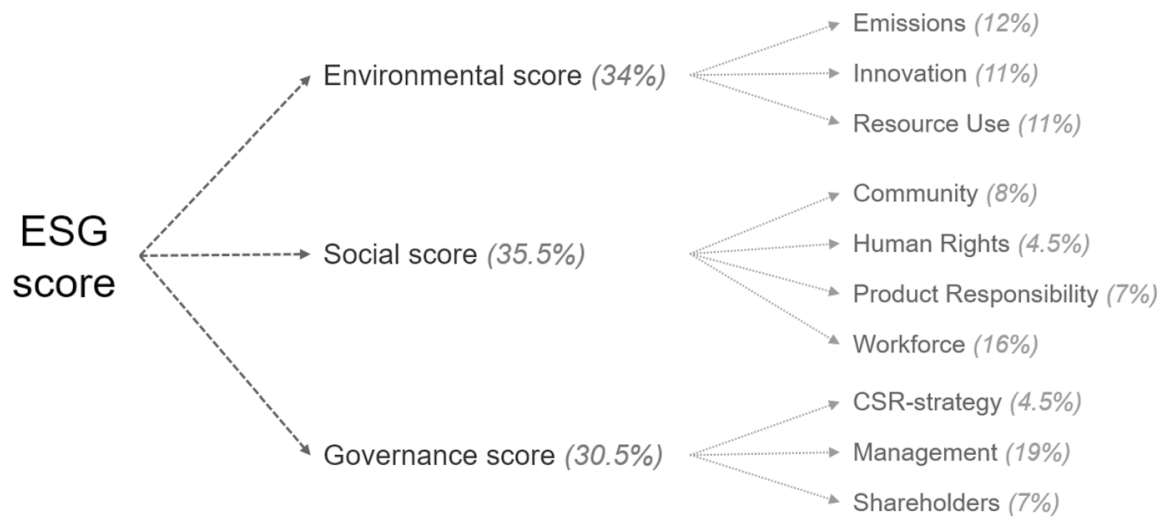

Fig. 1 Composition of the Thomson Reuters ESG score. The graph shows the breakdown of the ESG score into its three pillars and its ten sub-components, as well as their weightings in the total score

the lowest weights in the total score (4.5\%). With 34 metrics, information on Management is the most transparent and gets the largest weight in the total score (19\%). Each metric is calculated as a percentage rank score (in relation to an industry benchmark). As a data source, Thomson Reuters uses publicly available companyreported information (Refinitiv 2021).

The availability of the ESG scores is the restricting factor of our time series since they were not available before 2002. In order to enable the calculation of metrics like the standard deviation of return on assets (ROA), we collected additional fundamental data from 1997 to 2002 . To control for country-specific effects, we retrieved macroeconomic data from the WorldBank database. Our final dataset comprises longitudinal data on 582 banks from 2002 to 2018. Figure 2 in the Appendix provides information about the origin of the banks. To ensure that our results are not driven by severe outliers and single erroneous data points, the data is winsorised at the 1st and the 99th percentile. Winsorisation is not applied to dummy variables and data on ESG scores, because they are subject to multiple checks and controls by Thomson Reuters.

\subsection{Dependent variable and risk measures}

In order to measure the impact of CSR on bank risk, we focus on accounting-based risk measures. This allows us to analyse listed and unlisted banks. In particular, we consider both banks' default risk and portfolio risk.

We approximate default risk by different specifications of the z-score, which compares a bank's ROA plus its capital adequacy ratio (CAR) with the standard deviation of ROA (Boyd et al. 1993; Laeven and Levine 2009). The CAR is defined as the ratio of equity to total assets (Houston et al. 2010). We calculate the standard 
Table 1 Summary statistics of variables included

\begin{tabular}{lllllllll}
\hline Variables & $(1)$ & $(2)$ & $(3)$ & $(4)$ & $(5)$ & $(6)$ & $(7)$ & $(8)$ \\
& $\mathrm{N}$ & Min & $25 \%$ & $50 \%$ & Mean & $75 \%$ & Max & sd \\
\hline Panel A & & & & & & & & \\
Z-score & 4143 & -0.39 & 16.34 & 31.10 & 46.31 & 57.92 & 959.86 & 50.42 \\
RD & 2980 & 0.06 & 48.43 & 63.96 & 62.59 & 76.83 & 579.31 & 25.56 \\
Panel B & & & & & & & & \\
ESG score & 4143 & 12.30 & 35.20 & 48.09 & 50.86 & 66.46 & 93.53 & 18.94 \\
EnvPillar & 4143 & 7.67 & 29.29 & 45.91 & 51.00 & 73.75 & 98.10 & 24.83 \\
SocPillar & 4143 & 2.65 & 34.32 & 49.40 & 50.72 & 66.81 & 98.01 & 21.54 \\
GovPillar & 4143 & 1.72 & 32.94 & 51.27 & 50.85 & 69.13 & 99.52 & 21.81 \\
Panel C & & & & & & & & 10.36 \\
logFTE & 3787 & 1.39 & 7.80 & 9.20 & 9.10 & 10.36 & 12.15 & 1.66 \\
LR & 4143 & $-16,986,120.31$ & 718.68 & 1025.58 & $-11,862.49$ & 1569.98 & $21,030.75$ & $392,593.30$ \\
LoanRatio & 3654 & 0.02 & 51.15 & 62.52 & 60.29 & 70.19 & 93.51 & 14.25 \\
DepRatio & 3661 & 0.23 & 60.38 & 72.17 & 68.71 & 80.36 & 98.76 & 15.53 \\
ROE & 4143 & $-10,271.65$ & 9.46 & 14.20 & 71.42 & 19.83 & $49,600.56$ & 1556.94 \\
\hline
\end{tabular}

This table provides summary statistics on the variables and data considered in our analyses. The restricting factor is the availability of the ESG scores. The data is winsorised at the 1st and the 99th percentile. Panel A shows the statistics of the risk measures, Panel B of the ESG score and its pillars, and Panel C of the bank specific control variables included

deviation of ROA for rolling windows of 5 years in our baseline scenario. ${ }^{6}$ Thus, the $\mathrm{z}$-score is defined as the number of standard deviations the ROA has to drop below its mean until equity is entirely depleted. In this way, the z-score represents a measure of the risk that a bank becomes insolvent. The higher the $\mathrm{z}$-score, the more secure the bank.

$$
z \text {-score }_{i, t}=\frac{\left(R O A_{i, t}+C A R_{i, t}\right)}{\sigma\left(R O A_{i, t}\right)}
$$

Portfolio risk is approximated by the risk density (RD), which is calculated as the amount of risk-weighted assets (RWA) over total assets reported on the balance sheet (Le Leslé and Avramova 2012; Baule and Tallau 2016). RWA are reported by the banks as a key regulatory indicator necessary to compute risk-sensitive regulatory CARs. In order to compute RWA, banks multiply each asset with a regulatory risk weight. RD is therefore supposed to reflect the total riskiness of a bank's assets.

$$
R D_{i, t}=\frac{\text { Risk-weighted-assets }_{i, t}}{\text { Total-assets }_{i, t}}
$$

\footnotetext{
6 There is no consensus about the adequate time frame of the rolling window in the literature (Schulte and Winkler 2019). Five years, however, is a widely recognised horizon. We apply a time frame of 10 years in the robustness section as well.
} 
Table 10 in the Appendix summarises all the variables used in this study. Descriptive statistics on the risk measures based on non-winsorised data are provided in Panel A of Table 1.

\subsection{ESG scores and control variables}

We approximate the CSR of a bank by its Thomson Reuters ESG score. Thereby, we differentiate the three pillars constituting the overall score, as well as for each subcomponent within each pillar. This enables us to perform an determinant analysis for each of the ten sub-components in order to study the relationship of CSR and risk in more detail.

Descriptive statistics on the ESG score and its three pillars are provided in Panel B of Table 1. All the scores, as well as the sub-components, are standardised between 0 and 100. A visible and important insight for the statistical analysis is that the distributions of the scores have variation and are not static. Table 11 in the Appendix provides additional information on the correlation of the three pillars and the risk measures.

In order to mitigate omitted variable bias, we use several bank- and country-specific control variables in the multivariate regression models. Bank specifics are variables that characterise a particular bank, while macroeconomic variables are not specific to a particular bank but rather to a group of banks (e.g. country-specific). On the bank level, we control for size, capital structure, profitability, and the business model of banks. We approximate size by the natural logarithm of full-time employees (logFTE). We use full-time employees instead of total assets in order to reduce issues with multicollinearity. ${ }^{7}$ The bank's capital structure is approximated by the leverage ratio (LR) calculated as liabilities over equity and profitability as return on equity (ROE). Based on the differentiation of business models by Ayadi et al. (2016), we also consider the loans to assets ratio (LoanRatio) and the deposits to assets ratio (DepRatio). On the country level, we control for inflation, GDPgrowth $\left(\mathrm{GDP}_{\text {Cap }}^{\text {Growth }}\right)$, and GDP per capita $\left(\mathrm{GDP}_{\mathrm{Cap}}\right)$.

\subsection{Methodology}

In order to study the effect of CSR on bank risk, we apply a series of univariate and multivariate linear fixed effects (FE) regression models. The model is specified as follows:

$$
\operatorname{Risk}_{i, t+1}=\alpha_{i}+\delta * E S G_{i, t}+\boldsymbol{\beta} * X_{i, t}+\gamma * Y_{j, t}+\mu_{t}+\epsilon_{i, t},
$$

while $X$ comprises the bank specific variables and $Y$ comprises the macroeconomic variables. The indices indicate: $i=$ bank; $j=$ country; $t=$ fiscalyear.

\footnotetext{
7 The choice of the proxy for size does not affect our results. The explanatory power of our model and the significance of the variables included does not differ substantially compared with the use of log total assets.
} 
Risk $_{i, t}$ indicates the observation of one of the risk measures used at time $t$ at bank i. $E S G_{i, t}$ approximates the CSR of bank $i$ at time $t$, and is specified as the ESG score, one of its three pillars, or one of the ten sub-components. The baseline models consider 1 year lagged independent variables in order to mitigate endogeneity by a potential reverse causality or simultaneity bias. In Sect. 5, we consider a 2-year lag as well.

The regression models are specified with bank and time FEs, to account for unobserved heterogeneity that may be correlated with the explanatory variables. The Hausman tests suggest that coefficient estimates in fixed and random effects models are not alike (with p-values $<1 \%$ ), therefore suggesting the rejection of random effects. Robust Huber-White-sandwich estimates of variance are used for the

Table 2 Multivariate robust FE regressions of risk on the ESG score

\begin{tabular}{|c|c|c|c|c|c|c|}
\hline & & & (3) & (4) & $(5)$ & (6) \\
\hline & z-score & z-score & z-score & $\mathrm{RD}$ & $\mathrm{RD}$ & $\mathrm{RD}$ \\
\hline & Coef./se & Coef./se & Coef./se & Coef./se & Coef./se & Coef./se \\
\hline L.ESG score & $\begin{array}{l}0.8061 * * * \\
(0.09)\end{array}$ & $\begin{array}{l}0.7749 * * * \\
(0.09)\end{array}$ & $\begin{array}{l}0.6176^{* * * *} \\
(0.10)\end{array}$ & $\begin{array}{l}-0.1598^{* * * *} \\
(0.05)\end{array}$ & $\begin{array}{l}-0.1368^{*} \\
(0.07)\end{array}$ & $\begin{array}{l}-0.1572 * * \\
(0.07)\end{array}$ \\
\hline L. $\log$ FTE & & $\begin{array}{l}0.1783 \\
(4.19)\end{array}$ & $\begin{array}{l}2.2885 \\
(4.12)\end{array}$ & & $\begin{array}{l}-3.9859 \\
(5.57)\end{array}$ & $\begin{array}{l}-3.2291 \\
(5.74)\end{array}$ \\
\hline L.LR & & $\begin{array}{l}-0.0000 * * * \\
(0.00)\end{array}$ & $\begin{array}{l}-0.0000^{* * *} \\
(0.00)\end{array}$ & & $\begin{array}{l}0.0000 \\
(0.00)\end{array}$ & $\begin{array}{l}0.0000 \text { ** } \\
(0.00)\end{array}$ \\
\hline L.LoanRatio & & $\begin{array}{l}0.1448 \\
(0.16)\end{array}$ & $\begin{array}{l}0.1201 \\
(0.16)\end{array}$ & & $\begin{array}{l}0.2757 * * \\
(0.12)\end{array}$ & $\begin{array}{l}0.2782 * * \\
(0.12)\end{array}$ \\
\hline L.DepRatio & & $\begin{array}{l}0.3383 * * * \\
(0.11)\end{array}$ & $\begin{array}{l}0.2507 * * \\
(0.11)\end{array}$ & & $\begin{array}{l}-0.0977 \\
(0.13)\end{array}$ & $\begin{array}{l}-0.1013 \\
(0.14)\end{array}$ \\
\hline L.ROE & & $\begin{array}{l}-0.0010^{* * *} \\
(0.00)\end{array}$ & $\begin{array}{l}-0.0006^{* *} \\
(0.00)\end{array}$ & & $\begin{array}{l}-0.0001 \\
(0.00)\end{array}$ & $\begin{array}{l}0.0000 \\
(0.00)\end{array}$ \\
\hline L.Inflation & & & $\begin{array}{l}-0.0277 \\
(0.35)\end{array}$ & & & $\begin{array}{l}0.0333 \\
(0.10)\end{array}$ \\
\hline L.GDP Growth & & & $\begin{array}{l}1.2607 * * * \\
(0.36)\end{array}$ & & & $\begin{array}{l}0.3616^{*} \\
(0.19)\end{array}$ \\
\hline L.GDP ${ }_{\text {Cap }}$ & & & $\begin{array}{l}0.0016 \\
(0.00)\end{array}$ & & & $\begin{array}{l}0.0000 \\
(0.00)\end{array}$ \\
\hline Constant & $\begin{array}{l}6.3560 \\
(4.75)\end{array}$ & $\begin{array}{l}-24.7530 \\
(39.97)\end{array}$ & $\begin{array}{l}-91.1087^{*} \\
(47.32)\end{array}$ & $\begin{array}{l}70.3927 * * * \\
(2.78)\end{array}$ & $\begin{array}{l}96.1081 \\
(60.31)\end{array}$ & $\begin{array}{l}87.9577 \\
(61.69)\end{array}$ \\
\hline $\mathrm{N}$ & 3949 & 3200 & 3117 & 2904 & 2674 & 2635 \\
\hline $\mathbf{R}_{a d j}^{2}$ & 0.0413 & 0.0450 & 0.0611 & 0.0059 & 0.0107 & 0.0119 \\
\hline
\end{tabular}

The table shows the coefficients and standard errors (in parenthesis) of multivariate robust FE regressions. The dependent variables are the bank risk measures z-score and RD. The independent variables are the ESG score and bank and country specific control variables. The independent variables are 1 year lagged. Significance is denoted at the $10 \%\left(^{*}\right), 5 \%\left({ }^{* *}\right)$, and $1 \%\left({ }^{* *}\right)$ significance level. Data is winsorised at the 1 st and the 99 th percentile 
statistical analysis to account for group-wise heteroscedasticity in the residuals of the regression models (Froot 1989; Williams 2000).

\section{Results}

Table 2 summarises the results of panel regressions of bank risk on the overall ESG score as a measure for banks' total CSR. Models 1-3 show the results for the z-score as a measure for default risk, while Models 4-6 illustrate the results for RD as a measure for portfolio risk. Models 1 and 4 depict univariate regression results, without any control variables. The coefficient in Model 1 is positive and statistically significant at the $1 \%$ level. This indicates that the ESG score in the previous year increases the z-score and therefore lowers the default risk of the bank. Model 2 includes additional bank-specific control variables, while Model 3 includes countryspecific control variables as well. Both coefficients remain positive and highly statistically significant, supporting the result that the ESG score increases the z-score, thereby reducing banks' default risk. Concerning the economical relevance, we interpret that an increase of the ESG score by one unit is associated with a 0.62 higher z-score. The coefficients in Models 4-6 for the effect on RD are all negative and statistically significant. This indicates that CSR reduces the RD (i.e., the portfolio risk of a bank). Model 4 for the univariate results implies significance at the $1 \%$ level. The results remain negative and statistically significant if bank-specific control variables are included (Model 5) and if country-specific variables are included (Model 6). An increase of one unit of the ESG score is associated with a decrease of the RD of 0.16 percentage points. Taken together, the results indicate that banks' CSR activities on aggregate reduce the default and portfolio risk. Overall, the results are in line with risk management theory and provide empirical evidence for our first hypothesis.

In Hypothesis 2, we examine the interaction of the various CSR components with bank risk. Tables 3, 4 and 5 provide the multivariate regression results for each of the three pillars of the total ESG score. For the environmental pillar (Table 3), we find highly statistically significant effects in the univariate Model 1 and Model 4. These results are robust to bank-specific controls (Model 2 and Model 5) and country-specific controls (Model 3 and Model 6) at the 1\% level. Consequently, the environmental pillar has a risk-reducing effect on bank risk, as measured by both risk indicators. This is in line with Hypothesis 2.

Table 4 illustrates that for the social pillar of the ESG score, the results are not as unanimous as for the environmental pillar. Instead, the results depend on the bank risk proxies. As for the environmental pillar, we find highly significant coefficients in Models 1-3 for the social pillar on the z-score that approximates the banks' default risk. For the coefficients for RD in Models 4-6 approximating portfolio risk, however, we cannot find statistical significance, even though the direction of the coefficients is in line with expectation.

Table 5 provides the results for the governance pillar of the ESG score. Again, we find highly significant coefficients in Models 1-3 for the governance pillar of the ESG score, while for the RD, we only find statistical significance in the univariate 
Table 3 Multivariate robust FE regressions of risk on the environmental score

\begin{tabular}{|c|c|c|c|c|c|c|}
\hline & (1) & (2) & (3) & (4) & (5) & (6) \\
\hline & Z-score & z-score & z-score & $\mathrm{RD}$ & $\mathrm{RD}$ & $\mathrm{RD}$ \\
\hline & Coef./se & Coef./se & Coef./se & Coef./se & Coef./se & Coef./se \\
\hline L.EnvPillar & $\begin{array}{l}0.5589 * * * \\
(0.07)\end{array}$ & $\begin{array}{l}0.5415^{* * *} \\
(0.07)\end{array}$ & $\begin{array}{l}0.4393 * * * \\
(0.08)\end{array}$ & $\begin{array}{l}-0.1359 * * * \\
(0.04)\end{array}$ & $\begin{array}{l}-0.1296^{* * * *} \\
(0.04)\end{array}$ & $\begin{array}{l}-0.1436 * * * \\
(0.04)\end{array}$ \\
\hline L.logFTE & & $\begin{array}{l}0.8016 \\
(4.23)\end{array}$ & $\begin{array}{l}2.5585 \\
(4.13)\end{array}$ & & $\begin{array}{l}-3.5049 \\
(5.29)\end{array}$ & $\begin{array}{l}-2.7782 \\
(5.43)\end{array}$ \\
\hline L.LR & & $\begin{array}{l}-0.0000 * * * \\
(0.00)\end{array}$ & $\begin{array}{l}-0.0000 * * * \\
(0.00)\end{array}$ & & $\begin{array}{l}0.0000 \\
(0.00)\end{array}$ & $\begin{array}{l}0.0000 * * \\
(0.00)\end{array}$ \\
\hline L.LoanRatio & & $\begin{array}{l}0.1412 \\
(0.16)\end{array}$ & $\begin{array}{l}0.1150 \\
(0.16)\end{array}$ & & $\begin{array}{l}0.2854 * * \\
(0.12)\end{array}$ & $\begin{array}{l}0.2880^{* * *} \\
(0.12)\end{array}$ \\
\hline L.DepRatio & & $\begin{array}{l}0.3986^{* * * *} \\
(0.11)\end{array}$ & $\begin{array}{l}0.2990 * * * \\
(0.11)\end{array}$ & & $\begin{array}{l}-0.1142 \\
(0.13)\end{array}$ & $\begin{array}{l}-0.1204 \\
(0.13)\end{array}$ \\
\hline L.ROE & & $\begin{array}{l}-0.0010^{* * * *} \\
(0.00)\end{array}$ & $\begin{array}{l}-0.0006^{* *} \\
(0.00)\end{array}$ & & $\begin{array}{l}-0.0000 \\
(0.00)\end{array}$ & $\begin{array}{l}0.0000 \\
(0.00)\end{array}$ \\
\hline L.Inflation & & & $\begin{array}{l}-0.0440 \\
(0.35)\end{array}$ & & & $\begin{array}{l}0.0220 \\
(0.10)\end{array}$ \\
\hline L.GDP ${ }_{\text {Cap }}^{\text {Growth }}$ & & & $\begin{array}{l}1.2126^{* * * *} \\
(0.36)\end{array}$ & & & $\begin{array}{l}0.3633^{*} \\
(0.19)\end{array}$ \\
\hline L.GDP ${ }_{\text {Cap }}$ & & & $\begin{array}{l}0.0016 \\
(0.00)\end{array}$ & & & $\begin{array}{l}0.0001 \\
(0.00)\end{array}$ \\
\hline Constant & $\begin{array}{l}18.7935^{* * * *} \\
(3.52)\end{array}$ & $\begin{array}{l}-22.5995 \\
(41.21)\end{array}$ & $\begin{array}{l}-88.3094 * \\
(47.69)\end{array}$ & $\begin{array}{l}69.2300 * * * \\
(1.94)\end{array}$ & $\begin{array}{l}91.9350 \\
(58.49)\end{array}$ & $\begin{array}{l}83.2806 \\
(59.38)\end{array}$ \\
\hline $\mathrm{N}$ & 3949 & 3200 & 3117 & 2904 & 2674 & 2635 \\
\hline $\mathbf{R}_{a d j}^{2}$ & 0.0402 & 0.0451 & 0.0622 & 0.0088 & 0.0138 & 0.0153 \\
\hline
\end{tabular}

The table shows the coefficients and standard errors (in parenthesis) of multivariate robust FE regressions. The dependent variables are the bank risk measures $\mathrm{z}$-score and RD. The independent variables are the ESG environmental pillar score (EnvPillar) and bank and country specific control variables. The independent variables are 1 year lagged. Significance is denoted at the $10 \%\left({ }^{*}\right), 5 \%\left({ }^{* *}\right)$, and $1 \%\left(^{* * *}\right)$ significance level. Data is winsorised at the 1st and the 99th percentile

Model 4. The results in Models 5-6, including bank-specific and country-specific control variables, show no statistical significance.

So far, we found that the risk-reducing effect differs between the pillars. In general, all pillars reduce default risk measured by the z-score. In addition, the environmental pillar also affects the portfolio risk with statistical significance. Taken together, the environmental pillar shows the strongest effects in magnitude and significance and is the only pillar with clear and unequivocal effects. However, the identification of single risk drivers within the three pillars is not possible at this stage, thus we explore the risk-reducing effects of the ten sub-components of the total ESG score in the following step. Considering the different weights of the ten sub-components, this procedure contributes to the validity of our results 
Table 4 Multivariate robust FE regressions of risk on the social score

\begin{tabular}{|c|c|c|c|c|c|c|}
\hline & (1) & (2) & (3) & (4) & (5) & (6) \\
\hline & Z-score & Z-score & Z-score & RD & $\mathrm{RD}$ & $\mathrm{RD}$ \\
\hline & Coef./se & Coef./se & Coef./se & Coef./se & Coef./se & Coef./se \\
\hline \multirow[t]{2}{*}{ L.SocPillar } & $0.5181 * * *$ & $0.4579 * * *$ & $0.2958 * * *$ & -0.0549 & -0.0342 & -0.0441 \\
\hline & $(0.08)$ & $(0.08)$ & $(0.09)$ & $(0.04)$ & $(0.05)$ & $(0.05)$ \\
\hline \multirow[t]{2}{*}{ L.logFTE } & & 4.1909 & 6.2426 & & -5.3885 & -4.7190 \\
\hline & & $(4.48)$ & $(4.43)$ & & (5.37) & $(5.53)$ \\
\hline \multirow[t]{2}{*}{ L.LR } & & $-0.0000 * * *$ & $-0.0000^{* * * *}$ & & 0.0000 & $0.0000 * *$ \\
\hline & & $(0.00)$ & $(0.00)$ & & $(0.00)$ & $(0.00)$ \\
\hline \multirow[t]{2}{*}{ L.LoanRatio } & & 0.1876 & 0.1566 & & $0.2643 * *$ & $0.2680 * *$ \\
\hline & & $(0.16)$ & $(0.17)$ & & $(0.12)$ & $(0.12)$ \\
\hline \multirow[t]{2}{*}{ L.DepRatio } & & $0.3390 * * *$ & $0.2475^{* *}$ & & -0.1040 & -0.1070 \\
\hline & & $(0.11)$ & $(0.12)$ & & $(0.13)$ & $(0.13)$ \\
\hline \multirow[t]{2}{*}{ L.ROE } & & $-0.0009 * * *$ & $-0.0005^{* *}$ & & -0.0001 & 0.0000 \\
\hline & & $(0.00)$ & $(0.00)$ & & $(0.00)$ & $(0.00)$ \\
\hline \multirow[t]{2}{*}{ L.Inflation } & & & -0.2096 & & & 0.0802 \\
\hline & & & $(0.35)$ & & & $(0.11)$ \\
\hline \multirow[t]{2}{*}{ L.GDP ${ }_{\text {Cap }}^{\text {Growth }}$} & & & $1.1619^{* * *}$ & & & $0.3823^{* *}$ \\
\hline & & & $(0.36)$ & & & $(0.19)$ \\
\hline \multirow[t]{2}{*}{ L.GDP $_{\text {Cap }}$} & & & $0.0018 *$ & & & -0.0000 \\
\hline & & & $(0.00)$ & & & $(0.00)$ \\
\hline \multirow[t]{2}{*}{ Constant } & $21.2068 * * *$ & -48.0482 & $-119.3424 * *$ & $64.8943 * * *$ & $104.8033^{*}$ & $99.2207 *$ \\
\hline & $(3.81)$ & $(43.38)$ & $(50.89)$ & $(1.87)$ & $(58.73)$ & $(59.85)$ \\
\hline $\mathrm{N}$ & 3949 & 3200 & 3117 & 2904 & 2674 & 2635 \\
\hline $\mathbf{R}_{a d j}^{2}$ & 0.0236 & 0.0278 & 0.0480 & 0.0006 & 0.0073 & 0.0079 \\
\hline
\end{tabular}

The table shows the coefficients and standard errors (in parenthesis) of multivariate robust FE regressions. The dependent variables are the bank risk measures $\mathrm{z}$-score and RD. The independent variables are the ESG social pillar score (SocPillar) and bank and country specific control variables. The independent variables are 1 year lagged. Significance is denoted at the $10 \%\left({ }^{*}\right), 5 \%\left(^{* *}\right)$, and $1 \%\left(^{* * *}\right)$ significance level. Data is winsorised at the 1 st and the 99 th percentile

and leads to a profound understanding of the effects of the three pillars. The findings for multivariate regressions are depicted in Table 6.

The environmental pillar consists of the sub-components Emissions, Environmental Innovation, and Resource Use. The Emissions score reflects a bank's self-commitment to emissions reduction, while Environmental Innovation reflects a bank's capacity to develop and support eco-friendly products and processes, thereby reducing ecological costs for its customers. In the case of banks, this can be the integration of ecological factors into their lending practice (e.g. the Equator Principles) that leads to lower credit risk, which explains the risk reduction (credit risk channel). Lastly, Resource Use measures the efficiency of a firm's resource usage. Given the significances, all three sub-components show a riskreducing effect, considering the default and portfolio risk. The results are also in 
Table 5 Multivariate robust FE regressions of risk on the governance score

\begin{tabular}{|c|c|c|c|c|c|c|}
\hline & (1) & (2) & (3) & (4) & (5) & (6) \\
\hline & z-score & z-score & z-score & RD & RD & $\mathrm{RD}$ \\
\hline & Coef./se & Coef./se & Coef./se & Coef./se & Coef./se & Coef./se \\
\hline L.GovPillar & $\begin{array}{l}0.2886^{* * *} \\
(0.06)\end{array}$ & $\begin{array}{l}0.2710^{* * *} \\
(0.06)\end{array}$ & $\begin{array}{l}0.2264 * * * \\
(0.06)\end{array}$ & $\begin{array}{l}-0.0727^{*} \\
(0.04)\end{array}$ & $\begin{array}{l}-0.0474 \\
(0.05)\end{array}$ & $\begin{array}{l}-0.0502 \\
(0.05)\end{array}$ \\
\hline L. $\log$ FTE & & $\begin{array}{l}8.9838^{*} \\
(4.57)\end{array}$ & $\begin{array}{l}8.8121^{* *} \\
(4.40)\end{array}$ & & $\begin{array}{l}-5.4582 \\
(5.15)\end{array}$ & $\begin{array}{l}-4.9101 \\
(5.30)\end{array}$ \\
\hline L.LR & & $\begin{array}{l}-0.0000^{* * * *} \\
(0.00)\end{array}$ & $\begin{array}{l}-0.0000^{* *} \\
(0.00)\end{array}$ & & $\begin{array}{l}0.0000 \\
(0.00)\end{array}$ & $\begin{array}{l}0.0000^{* * *} \\
(0.00)\end{array}$ \\
\hline L.LoanRatio & & $\begin{array}{l}0.2188 \\
(0.16)\end{array}$ & $\begin{array}{l}0.1741 \\
(0.17)\end{array}$ & & $\begin{array}{l}0.2614 * * \\
(0.12)\end{array}$ & $\begin{array}{l}0.2638^{* * *} \\
(0.12)\end{array}$ \\
\hline L.DepRatio & & $\begin{array}{l}0.3234 * * * \\
(0.11)\end{array}$ & $\begin{array}{l}0.2268^{*} \\
(0.12)\end{array}$ & & $\begin{array}{l}-0.0936 \\
(0.14)\end{array}$ & $\begin{array}{l}-0.0959 \\
(0.14)\end{array}$ \\
\hline L.ROE & & $\begin{array}{l}-0.0007 * * * \\
(0.00)\end{array}$ & $\begin{array}{l}-0.0004^{* *} \\
(0.00)\end{array}$ & & $\begin{array}{l}-0.0001 \\
(0.00)\end{array}$ & $\begin{array}{l}-0.0000 \\
(0.00)\end{array}$ \\
\hline L.Inflation & & & $\begin{array}{l}-0.2330 \\
(0.36)\end{array}$ & & & $\begin{array}{l}0.0768 \\
(0.11)\end{array}$ \\
\hline L.GDP ${ }_{\text {Cap }}^{\text {Growth }}$ & & & $\begin{array}{l}1.2033^{* * * *} \\
(0.36)\end{array}$ & & & $\begin{array}{l}0.3689 * * \\
(0.19)\end{array}$ \\
\hline L.GDP ${ }_{\text {Cap }}$ & & & $\begin{array}{l}0.0019^{*} \\
(0.00)\end{array}$ & & & $\begin{array}{l}-0.0000 \\
(0.00)\end{array}$ \\
\hline Constant & $\begin{array}{l}32.8002 * * * \\
(3.14)\end{array}$ & $\begin{array}{l}-83.2546^{*} \\
(45.56)\end{array}$ & $\begin{array}{l}-141.8616 * * * \\
(48.49)\end{array}$ & $\begin{array}{l}65.7275 * * * \\
(2.00)\end{array}$ & $\begin{array}{l}105.5128 * \\
(57.35)\end{array}$ & $\begin{array}{l}100.7562 * \\
(58.12)\end{array}$ \\
\hline $\mathrm{N}$ & 3949 & 3200 & 3117 & 2904 & 2674 & 2635 \\
\hline $\mathbf{R}_{a d j}^{2}$ & 0.0098 & 0.0203 & 0.0476 & 0.0021 & 0.0079 & 0.0084 \\
\hline
\end{tabular}

The table shows the coefficients and standard errors (in parenthesis) of multivariate robust FE regressions. The dependent variables are the bank risk measures z-score and RD. The independent variables are the ESG governance pillar score (GovPillar) and bank and country specific control variables. The independent variables are 1 year lagged. Significance is denoted at the $10 \%\left(^{*}\right), 5 \%\left(^{* *}\right)$, and $1 \%\left(^{* * *}\right)$ significance level. Data is winsorised at the 1st and the 99th percentile

line with risk management theory, and the three variables can be interpreted as indicators of managerial sophistication to reduce operative costs and contribute to higher and more stable income. They are also related to lower operational transformation risk and reputation risk. In this way, the sub-components of the environmental pillar reflect aspects of a forward-looking risk management approach. This also confirms our major finding that the environmental pillar as a whole has a risk-reducing effect on bank risk.

The sub-components Community, Human Rights, Product Responsibility, and Workforce are part of the social pillar. The Community score is a proxy of companies' ethical behavior and involvement with the society. However, we find no significance in any model, which means that the sub-component does not affect bank risk. Instead, we find high statistical significance for Human Rights in all six 
Table 6 Multivariate robust FE regressions of risk measures on the ten ESG sub-components

\begin{tabular}{|c|c|c|c|c|c|c|}
\hline & \multirow{2}{*}{$\begin{array}{l}\text { (1) } \\
\text { z-score }\end{array}$} & \multirow{2}{*}{$\begin{array}{l}\text { (2) } \\
\text { z-score }\end{array}$} & \multirow{2}{*}{$\begin{array}{l}\text { (3) } \\
\text { z-score }\end{array}$} & \multirow{2}{*}{$\begin{array}{l}(4) \\
\mathrm{RD}\end{array}$} & \multirow{2}{*}{$\begin{array}{l}\text { (5) } \\
\mathrm{RD}\end{array}$} & \multirow{2}{*}{$\begin{array}{l}\text { (6) } \\
\text { RD }\end{array}$} \\
\hline & & & & & & \\
\hline & Coef./se & Coef./se & Coef./se & Coef./se & Coef./se & Coef./se \\
\hline L.Env. Innovation & $\begin{array}{l}0.3282 * * * \\
(0.06)\end{array}$ & $\begin{array}{l}0.3296^{* * * *} \\
(0.06)\end{array}$ & $\begin{array}{l}0.2310^{* * *} \\
(0.06)\end{array}$ & $\begin{array}{l}-0.1302 * * * \\
(0.04)\end{array}$ & $\begin{array}{l}-0.1315^{* * *} \\
(0.05)\end{array}$ & $\begin{array}{l}-0.1465^{* * *} \\
(0.05)\end{array}$ \\
\hline L.Emissions & $\begin{array}{l}0.4007^{* * * *} \\
(0.05)\end{array}$ & $\begin{array}{l}0.3618^{* * * *} \\
(0.05)\end{array}$ & $\begin{array}{l}0.2880 * * * \\
(0.06)\end{array}$ & $\begin{array}{l}-0.0839 * * * \\
(0.03)\end{array}$ & $\begin{array}{l}-0.0733 * * \\
(0.03)\end{array}$ & $\begin{array}{l}-0.0800^{* *} \\
(0.03)\end{array}$ \\
\hline L.Resource Use & $\begin{array}{l}0.4639 * * * \\
(0.06)\end{array}$ & $\begin{array}{l}0.4279 * * * \\
(0.06)\end{array}$ & $\begin{array}{l}0.3644 * * * \\
(0.07)\end{array}$ & $\begin{array}{l}-0.0816^{* * * *} \\
(0.02)\end{array}$ & $\begin{array}{l}-0.0688 * * \\
(0.03)\end{array}$ & $\begin{array}{l}-0.0726^{* * *} \\
(0.03)\end{array}$ \\
\hline L.Community & $\begin{array}{l}0.0808 \\
(0.05)\end{array}$ & $\begin{array}{l}0.0322 \\
(0.06)\end{array}$ & $\begin{array}{l}-0.0391 \\
(0.05)\end{array}$ & $\begin{array}{l}-0.0202 \\
(0.03)\end{array}$ & $\begin{array}{l}-0.0131 \\
(0.03)\end{array}$ & $\begin{array}{l}-0.0157 \\
(0.03)\end{array}$ \\
\hline L.Human Rights & $\begin{array}{l}0.3037 * * * \\
(0.05)\end{array}$ & $\begin{array}{l}0.2674 * * * \\
(0.06)\end{array}$ & $\begin{array}{l}0.1602 * * * \\
(0.06)\end{array}$ & $\begin{array}{l}-0.1269 * * * \\
(0.02)\end{array}$ & $\begin{array}{l}-0.1165 * * * \\
(0.03)\end{array}$ & $\begin{array}{l}-0.1227^{* * *} \\
(0.03)\end{array}$ \\
\hline L.Product Respon. & $\begin{array}{l}0.1749 * * * \\
(0.06)\end{array}$ & $\begin{array}{l}0.1294 * * \\
(0.06)\end{array}$ & $\begin{array}{l}0.0385 \\
(0.06)\end{array}$ & $\begin{array}{l}0.0360 \\
(0.02)\end{array}$ & $\begin{array}{l}0.0509^{* *} \\
(0.03)\end{array}$ & $\begin{array}{l}0.0510 * \\
(0.03)\end{array}$ \\
\hline L.Workforce & $\begin{array}{l}0.3435^{* * * *} \\
(0.05)\end{array}$ & $\begin{array}{l}0.3182 * * * \\
(0.05)\end{array}$ & $\begin{array}{l}0.2486^{* * * *} \\
(0.06)\end{array}$ & $\begin{array}{l}-0.0396 \\
(0.03)\end{array}$ & $\begin{array}{l}-0.0310 \\
(0.04)\end{array}$ & $\begin{array}{l}-0.0374 \\
(0.04)\end{array}$ \\
\hline L.CSR-strategy & $\begin{array}{l}0.2440 * * * \\
(0.05)\end{array}$ & $\begin{array}{l}0.1742 * * * \\
(0.05)\end{array}$ & $\begin{array}{l}0.0890^{*} \\
(0.05)\end{array}$ & $\begin{array}{l}-0.0624 * * \\
(0.02)\end{array}$ & $\begin{array}{l}-0.0482 * \\
(0.03)\end{array}$ & $\begin{array}{l}-0.0557 * * \\
(0.03)\end{array}$ \\
\hline L.Management & $\begin{array}{l}0.1859 * * * \\
(0.04)\end{array}$ & $\begin{array}{l}0.1853 * * * \\
(0.04)\end{array}$ & $\begin{array}{l}0.1615^{* * *} \\
(0.04)\end{array}$ & $\begin{array}{l}-0.0307 \\
(0.02)\end{array}$ & $\begin{array}{l}-0.0164 \\
(0.03)\end{array}$ & $\begin{array}{l}-0.0178 \\
(0.03)\end{array}$ \\
\hline L.Shareholders & $\begin{array}{l}0.0150 \\
(0.04)\end{array}$ & $\begin{array}{l}0.0096 \\
(0.05)\end{array}$ & $\begin{array}{l}0.0116 \\
(0.05)\end{array}$ & $\begin{array}{l}-0.0423^{*} \\
(0.02)\end{array}$ & $\begin{array}{l}-0.0326 \\
(0.03)\end{array}$ & $\begin{array}{l}-0.0031 \\
(0.03)\end{array}$ \\
\hline Bank controls & No & Yes & Yes & No & Yes & Yes \\
\hline Country controls & No & No & Yes & No & No & Yes \\
\hline $\mathrm{N}$ & 3949 & 3200 & 3117 & 2904 & 2674 & 2635 \\
\hline
\end{tabular}

The table shows the coefficients and standard errors (in parenthesis) of multivariate robust FE regressions of risk on the ten different sub-components of the ESG score. Column (1) and (4) provide univariate results. The regression coefficients in column (2) and (5) account for bank specific control variables. Those in column (3) and (6) account for bank and country specific controls. The table shows only the coefficients of the variables of interest. Those of the control variables are not depicted. The independent variables are 1 year lagged. Significance is denoted at the $10 \%(*), 5 \%(* *)$, and $1 \%(* * *)$ significance level. Data is winsorised at the 1 st and the 99 th percentile

models. Human Rights, therefore, reduces both default risk as well as portfolio risk, and reflects the compliance with human rights and labour protection requirements. By renouncing the financing of, for example, the arms industry or companies with doubtful working standards (e.g. child labour in mines), banks, in particular, can contribute to the worldwide compliance with human rights. Otherwise, disregard potentially causes lawsuits constituting operational risk and severe reputational damage. The interaction is in line with risk management theory. Moreover, Product Responsibility is determined by product quality control programs, a highquality complaint management service, and the protection of sensitive customer 
data. However, we find conflicting results for this sub-component. The Workforce score only affects the z-score with high statistical significance. This underlines the value of good working conditions as well as ongoing employee qualification training. Nonetheless, it has no significance for RD. Notably, except for Human Rights, the sub-components of the social pillar do not statistically influence banks' portfolio risk. A reason for this could be the operationalization of the single sub-components by several indicators, which have no or only little influence on banks' RWA. For instance, most of the considered indicators do not influence the lending practice, thus the credit risk channel remains ineffective. Altogether, we find a strong dependence on the specific sub-components considered in the social pillar, even though we do not find any contradicting and significant effects. The inconclusive results for the Workforce score determine the effect of the aggregate social score. Workforce accounts for 16 of 35.5 percentage points, while the unambiguously significant subcomponent Human Rights accounts for only 4.5 percentage points.

The governance pillar consists of the sub-components for CSR-strategy, Management, and Shareholders. The CSR-strategy score measures the extent to which a bank communicates its consideration of social and environmental aspects in its decision-making processes and is the only sub-component within the governance pillar that has statistical significance in all six models. This result provides two implications: first, to the extent that talk corresponds with action, the effect can be interpreted as an active approach to managing risk, considering also environmental and social risks in day-to-day business. Second, through CSR reporting, which is part of the CSR-strategy, information asymmetries will be further reduced and risks mitigated. This finding is in line with the literature (Cui et al. 2018). For the sub-component Management, we observe high statistical significance for the z-score. However, we cannot find any statistical significance for the RD. The Management score measures the extent to which banks' corporate governance follows best practices. Our results indicate that such compliance affects default risk significantly but not portfolio risk. This indicates that good management practices reduce vulnerability to misconduct, which exposes the bank to additional default risk, but is not necessarily reflected in its RWAs. Moreover, the Shareholders score does not have statistical significance concerning the effects on the z-score. Also, it has no statistical significance on RD in Models 5-6, and only in the univariate Model 4 do we observe a low significance at the $10 \%$ level. This sub-component identifies the degree of fair treatment and protection of shareholders by the bank, including anti-takeover action. In particular, anti-takeover actions can serve as an intuitive explanation that this sub-component does not have a clear risk-reducing effect. Considering extreme actions like so-called 'poison pills' explains how such action can indeed lead to an increase in portfolio risk as well as default risk. In conclusion, we find mixed results for the sub-components of the governance pillar. The aggregate effect of the governance pillar is, however, dominated by the Management score, which accounts for 19 of 30.5 percentage points. In this way, the Management score explains why the effect of the aggregate governance score is not unambiguously risk reducing. 
Table 7 Multivariate robust FE regressions of risk on CSR

\begin{tabular}{|c|c|c|c|c|c|c|}
\hline & (1) & (2) & (3) & (4) & (5) & (6) \\
\hline & z-score & z-score & z-score & $\mathrm{RD}$ & $\mathrm{RD}$ & $\mathrm{RD}$ \\
\hline & Coef./se & Coef./se & Coef./se & Coef./se & Coef./se & Coef./se \\
\hline \multicolumn{7}{|l|}{ Without lag } \\
\hline ESG score & $\begin{array}{l}0.7169 * * * \\
(0.09)\end{array}$ & $\begin{array}{l}0.6900 * * * \\
(0.10)\end{array}$ & $\begin{array}{l}0.5526^{* * * *} \\
(0.11)\end{array}$ & $\begin{array}{l}-0.1211^{* * * *} \\
(0.04)\end{array}$ & $\begin{array}{l}-0.0838 \\
(0.06)\end{array}$ & $\begin{array}{l}-0.1020 * \\
(0.06)\end{array}$ \\
\hline EnvPillar & $\begin{array}{l}0.5274 * * * \\
(0.07)\end{array}$ & $\begin{array}{l}0.5015^{* * * *} \\
(0.07)\end{array}$ & $\begin{array}{l}0.4175^{* * * *} \\
(0.08)\end{array}$ & $\begin{array}{l}-0.1100 * * * \\
(0.03)\end{array}$ & $\begin{array}{l}-0.1224 * * * \\
(0.03)\end{array}$ & $\begin{array}{l}-0.1341^{* * *} \\
(0.03)\end{array}$ \\
\hline SocPillar & $\begin{array}{l}0.4465 * * * \\
(0.07)\end{array}$ & $\begin{array}{l}0.3495^{* * * *} \\
(0.08)\end{array}$ & $\begin{array}{l}0.2013 * * \\
(0.09)\end{array}$ & $\begin{array}{l}-0.0685^{*} \\
(0.04)\end{array}$ & $\begin{array}{l}-0.0695 \\
(0.05)\end{array}$ & $\begin{array}{l}-0.0813^{*} \\
(0.05)\end{array}$ \\
\hline GovPillar & $\begin{array}{l}0.2366^{* * * *} \\
(0.06)\end{array}$ & $\begin{array}{l}0.2235^{* * * *} \\
(0.06)\end{array}$ & $\begin{array}{l}0.1798 * * * \\
(0.06)\end{array}$ & $\begin{array}{l}-0.0242 \\
(0.03)\end{array}$ & $\begin{array}{l}-0.0089 \\
(0.04)\end{array}$ & $\begin{array}{l}-0.0092 \\
(0.04)\end{array}$ \\
\hline \multicolumn{7}{|l|}{2 years lagged } \\
\hline L2.ESG score & $\begin{array}{l}0.7421 * * * \\
(0.09)\end{array}$ & $\begin{array}{l}0.6945^{* * * *} \\
(0.09)\end{array}$ & $\begin{array}{l}0.5589^{* * *} \\
(0.10)\end{array}$ & $\begin{array}{l}-0.1700^{* * *} \\
(0.05)\end{array}$ & $\begin{array}{l}-0.1359 * * \\
(0.06)\end{array}$ & $\begin{array}{l}-0.1544 * * * \\
(0.06)\end{array}$ \\
\hline L2.EnvPillar & $\begin{array}{l}0.5214 * * * \\
(0.07)\end{array}$ & $\begin{array}{l}0.4962 * * * \\
(0.07)\end{array}$ & $\begin{array}{l}0.4041 * * * \\
(0.07)\end{array}$ & $\begin{array}{l}-0.1292 * * * \\
(0.04)\end{array}$ & $\begin{array}{l}-0.1082 * * * \\
(0.04)\end{array}$ & $\begin{array}{l}-0.1180^{* * *} \\
(0.04)\end{array}$ \\
\hline L2.SocPillar & $\begin{array}{l}0.4971 * * * \\
(0.08)\end{array}$ & $\begin{array}{l}0.4472 * * * \\
(0.08)\end{array}$ & $\begin{array}{l}0.3208^{* * * *} \\
(0.09)\end{array}$ & $\begin{array}{l}-0.0817 * \\
(0.05)\end{array}$ & $\begin{array}{l}-0.0576 \\
(0.04)\end{array}$ & $\begin{array}{l}-0.0661 \\
(0.04)\end{array}$ \\
\hline L2.GovPillar & $\begin{array}{l}0.2217 * * * \\
(0.07)\end{array}$ & $\begin{array}{l}0.2067 * * * \\
(0.07)\end{array}$ & $\begin{array}{l}0.1588 * * \\
(0.07)\end{array}$ & $\begin{array}{l}-0.0705^{* * *} \\
(0.03)\end{array}$ & $\begin{array}{l}-0.0402 \\
(0.03)\end{array}$ & $\begin{array}{l}-0.0388 \\
(0.03)\end{array}$ \\
\hline Bank controls & No & Yes & Yes & No & Yes & Yes \\
\hline Country controls & No & No & Yes & No & No & Yes \\
\hline
\end{tabular}

Robustness tests for different time lags. The table shows the coefficients and standard errors (in parenthesis) of multivariate robust FE regressions of risk on the ESG score, respectively its three pillars. Column (1) and (4) provide univariate results. The regression coefficients in column (2) and (5) account for bank specific control variables, in column (3) and (6) account for bank and country specific controls. The first panel provides results for variables of interest without time lag. The second panel provides results for variables of interest with a 2 years time lag. Significance is denoted at the $10 \%\left({ }^{*}\right), 5 \%\left({ }^{* *}\right)$, and $1 \%\left({ }^{* * *}\right)$ significance level. Data is winsorised at the 1 st and the 99th percentile

\section{Robustness}

In order to test the robustness of the results provided above, we perform a battery of additional tests. First, we re-estimate our aforementioned results by substituting all the variables of interest by the same variables with a 2-year lag, respectively without any time lag. This should ensure that the effects measured do not depend on the specific time lag considered. Table 7 provides the results for the ESG score and its three pillars. As illustrated, the results do not significantly change, and the ESG score remains highly significant for the z-score. For the RD, the ESG score has an even higher significance considering a 2-year lag, and the significance for the ESG score without a time lag is slightly lower. The environmental pillar remains significant in all models, independent of the time lag considered. The social pillar remains 
highly significant for the z-score. For the RD, the social pillar has no significance considering 1-year lagged variables, yet it is surprisingly weakly significant at the $10 \%$ level in two of three models if the variables are considered without time lag. The governance pillar remains highly significant for the z-score, although for RD it remains insignificant, except for the univariate model.

Second, we apply different levels of winsorisation to the data. We use winsorisation at 5th and the 95th\%-percentage levels to account for a broader definition of outliers. Alternatively, we abandon winsorisation and use the original data. These alternative procedures have no material effects on the coefficients of the variables of interest. As Tables 12, 13, 14 and 15 in the Appendix show, however, the explanatory power of the models is higher considering a winsorisation at the 5th and the 95th\% percentile levels. Some control variables gain additional significance as well.

Third, for the regression models performed throughout the study, we used panel OLS regression models with bank and time FEs following the Hausman test. However, the results hold as well if a maximum likelihood estimation model or a random effects estimation model is applied. In the latter case, we also consider the inclusion of additional time-invariate, country-specific control variables like those used by Laeven and Levine (2009): an index of the shareholder rights by Porta et al. (1998), a dummy variable that captures if the country has deposit insurance (from Laeven et al. (2008)), and an index of regulatory oversight of bank capital as well as an index of regulatory restrictions on the activities of banks, both from Barth et al. (2008). Their inclusion does not materially affect the regression models or the effects of our variables of interest-the ESG scores. As another alternative, we specify our regression models with country-FEs instead of bank-FEs. The results are similar to those of our baseline models (Tables 2, 3, 4 and 5).

Fourth, we consider additional country-specific control variables in our baseline models with bank-FEs. In this way, we investigate country specifics and further eliminate potential omitted variable bias. A prerequisite for the inclusion of additional country controls is a certain degree of variance over time, otherwise, they are already absorbed and controlled by the bank-FEs. Following Wu and Shen (2013), we enhance our FE models shown in Tables 2, 3, 4 and 5 by corruption and banking market concentration. We measure corruption as the perceived corruption provided by Transparency International's Corruption Perception Index. We capture banking market concentration as the share of the assets of the three largest banks per country in the countries' total amounts of banking assets (Bikker and Haaf 2002). Both variables increase the explanatory power of the regression models. While banking market concentration has no significant effects on the risk measures, corruption significantly increases portfolio risk. That means that the higher the corruption in a country, the higher the share of RWAs on the balance sheet. The effects of the ESG scores or the remaining variables in the regression models are, however, not materially affected by the addition of corruption and banking market concentration. The results that are not depicted here are available upon request.

Fifth, we further investigate whether the effects depend on invariate differences between the banks considered. In this way, we run our FE regression models separately for different sub-samples of our full sample. Our original sample was global, but following Demirgüç-Kunt and Levine (1999), we analyse sub-samples of banks 
from bank- versus market-based economies. Furthermore, we investigate whether a sub-sample of civil law countries yields different results compared with common law countries, motivated by the results of Miralles-Quirós et al. (2019). In both cases, we do not find elementary differences. These results are also available upon request.

Sixth, we perform specific robustness checks for the measurement of the z-score. In particular, we calculate the $\mathrm{z}$-score using standard deviations of ROA for rolling windows of ten instead of only 5 years. Even though 5 years is a widely appreciated window, 10 years should yield more reliable inputs. The results are robust to such an alternative calculation as well.

Table 8 Multivariate robust FE regressions of the two channels of the z-score on the ESG score

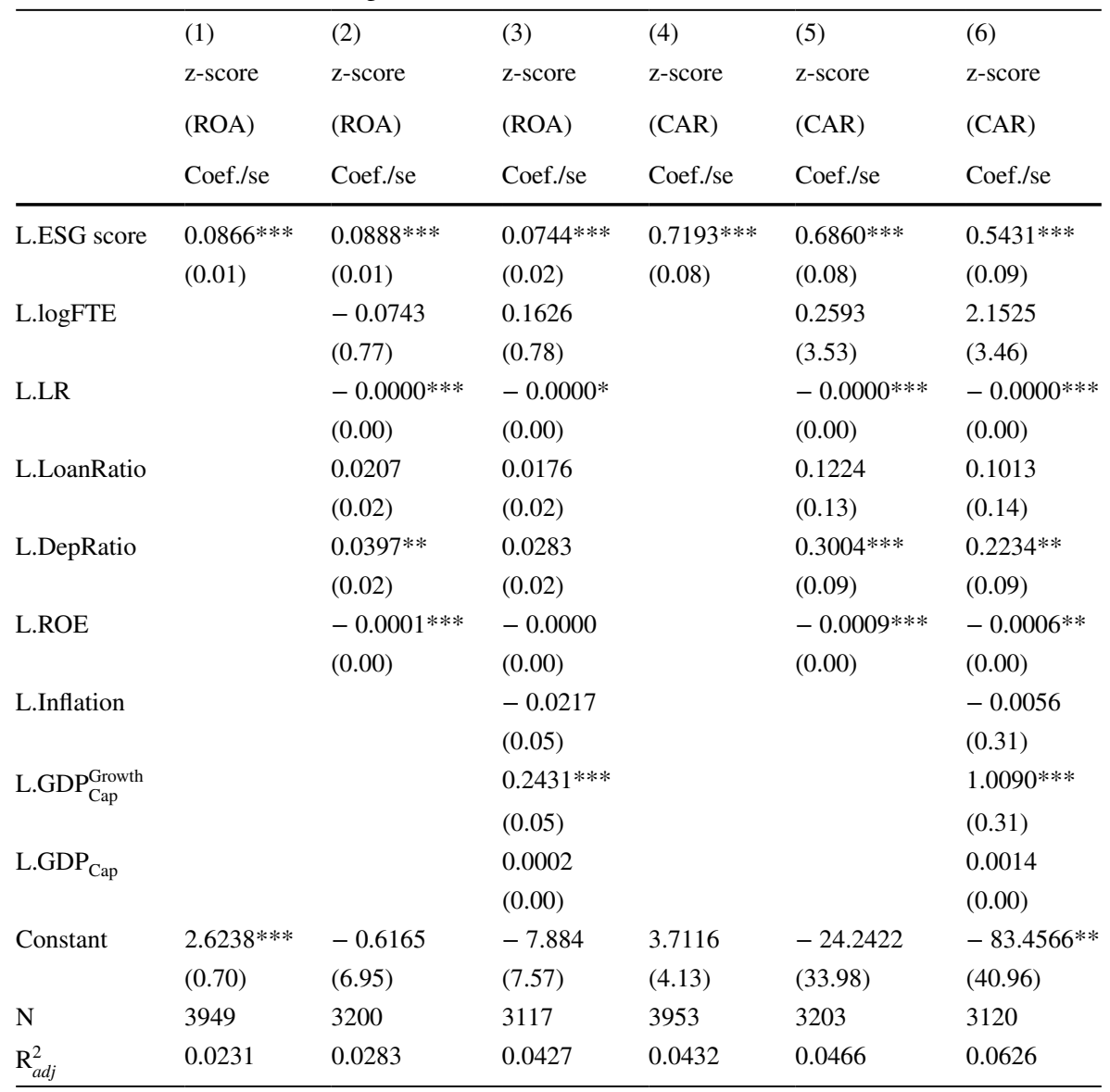

The table shows the coefficients and standard errors (in parenthesis) of multivariate robust FE regressions. The dependent variables are the different sub-components of the z-score, i.e. the risk-weighted ROA and the risk-weighted CAR. The independent variables are the ESG score and bank and country specific control variables. The independent variables are 1 year lagged. Significance is denoted at the $10 \%\left({ }^{*}\right), 5 \%\left({ }^{* *}\right)$, and $1 \%\left({ }^{* *}\right)$ significance level. Data is winsorised at the 1 st and the 99 th percentile 
Table 9 Multivariate robust FE regressions of the two channels of the z-score on the pillars and subcomponents of the ESG score

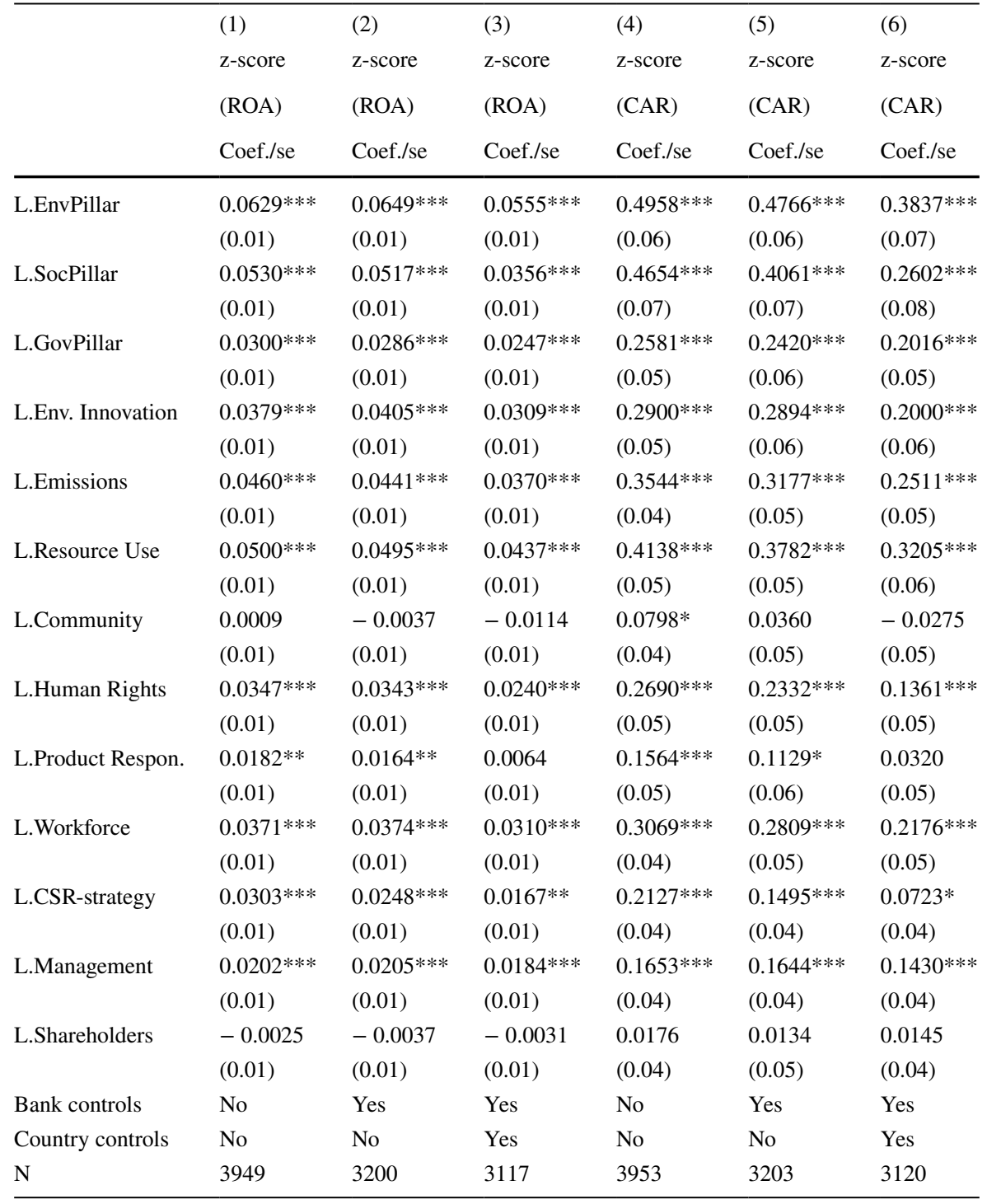

The table shows the coefficients and standard errors (in parenthesis) of multivariate robust FE regressions. The dependent variables are the different sub-components of the z-score, i.e. the risk-weighted ROA and the risk-weighted CAR. The independent variables are the ESG score, its three pillars, and ten sub-components. Control variables are not depicted. Column (1) and (4) provide univariate results. The regression coefficients in column (2) and (5) account for bank specific control variables. Those in column (3) and (6) account for bank and country specific controls. The independent variables are 1 year lagged. Significance is denoted at the $10 \%\left(^{*}\right), 5 \%(* *)$, and $1 \%\left(^{* * *}\right)$ significance level. Data is winsorised at the 1 st and the 99th percentile 
Seventh, analogous to Schulte and Winkler (2019), we separate the z-score into changes associated with ROA and changes associated with the CAR. Such a decomposition yields a measure of the z-score that relates only the ROA to the standard deviation of ROA. This can be interpreted as a risk-adjusted ROA.

$$
z-\operatorname{score}_{i, t}^{R O A}=\frac{R O A_{i, t}}{\sigma\left(R O A_{i, t}\right)}
$$

On the other hand, the decomposition yields a z-score measure relating only the CAR to the standard deviation of ROA. This can be interpreted as a risk-adjusted CAR.

$$
z \text { score }_{i, t}^{C A R}=\frac{C A R_{i, t}}{\sigma\left(R O A_{i, t}\right)}
$$

Table 8 illustrates the results for the separate regressions of the risk-adjusted ROA on the overall ESG score in Model 1-3 and for the risk-adjusted CAR in Model 4-6. The effect of the ESG score remains significant in all models. This implies that CSR affects bank default risk through both channels. Table 9 provides the coefficients of regressions of the risk-adjusted ROA in Model 1-3, respectively of the risk-adjusted CAR in Model 4-6, on the three pillars of the ESG score and its ten sub-components. Control variables are not depicted.

\section{Conclusions}

CSR has gained a lot of attention in recent years. Our study examines the relationship between CSR activities and bank risk. We contribute to the literature in the following ways: whereas the majority of studies explore the effects of CSR on firm risk for non-financial companies, our focus is specifically on banks. For this purpose, we use a data set of 582 banks worldwide, covering the period from 2002 to 2018. In order to address the bank specifics, we analyse the CSR effect on both default risk and portfolio risk. Namely, we use the z-score as a proxy for default risk and RD to measure portfolio risk. We examine the effect of CSR on bank risk at an aggregate CSR level, both individually for the three CSR pillars as well as for the pillars' ten sub-components. Our first hypothesis addresses the impact of overall CSR on banks' default risk and portfolio risk. We find strongly significant risk-reducing effects for both risk measures. The breakdown of the default risk measure $\mathrm{z}$-score into individual components indicates that CSR has a positive association with both risk-adjusted ROA and risk-adjusted CAR. On this basis, our second research question analyses the isolated effects of the environmental, social, and governance pillars on a bank's risk. In contrast to the 
overall results, the analysis of the individual pillars presents a slightly different picture. The risk-reducing effect of the environmental pillar still applies to both risk measures, yet for the social and governance pillars, there is only a statistically significant risk-reducing effect on default risk, but not on portfolio risk. In order to understand the reasons for these results, we conducted an analysis of the pillars' sub-components. The observed effects of all the sub-components of the environmental pillar are consistent with previous results. Thereby, it appears that all sub-components of this pillar (Emissions, Environmental Innovation, Resource Use) have a strongly significant impact on z-score and RD. This implies that the environmental pillar and its sub-components determine the risk reduction. Considering the social pillar and the governance pillar, we do not find unambiguous results. Only the sub-components Human Rights and CSR-strategy have unequivocally risk-reducing effects on both risk measures. To conclude, our empirical analysis supports our second hypothesis entirely concerning the environmental pillar, whereas only for specific sub-components of the social and the governance pillar, and so it can be unambiguously inferred that they reduce both bank risk measures. This means, as an implication for the risk management of banks, that integrating ESG factors into day-to-day business and lending activities reduces default and portfolio risk.

Our results have relevant theoretical and practical implications. From a scientific and analytical point of view, we contribute additional insights on influencing factors of banks' default and portfolio risk. From the bank management perspective, we provide an additional rationale to consider environmental aspects in particular. The association with lower bank risk should serve as encouragement and additional argument in internal decision-making processes. Because of the identified association, it is in the bank's own interest to improve its environmental CSR. From a regulator's and law maker's perspective, our results support attempts to foster CSRcompliant behavior.

We are aware of the limitations of our study. Certainly, one issue is the unbalanced panel structure. In addition, the unique use of the Thomson Reuters database carries the inherent risk of selection bias. Moreover, it could be interesting to use additional risk measures to enhance the validity of the results. However, due to a lack of data availability (e.g. Credit Default Swap spreads or non-performing loans), this is not feasible. Also, we are aware that we are not in a position to draw final conclusions about the suitability of a 'Green Supporting Factor', because we only have evidence on the relationship between environmental engagement and risk, but not on the average risk weight of a 'green' investment.

The following aspects could be interesting for further investigation. First, the validity of our results could be verified by using other risk measures, in particular market-based measures. Likewise, it might be useful to decompose the risk measure RD into single risk types (credit, market, and operational risk) to 
examine the impact of the ESG pillars and the sub-components on these different types of risk. In the same way, natural disasters like Fukushima or Hurricane Sandy could be used as a reference for natural experiments to investigate the relationship and test our results. These would, also, provide evidence on the perceived risk of market participants. Second, it is highly relevant to examine the interaction of CSR and bank risk with respect to widely known CSR motives, namely strategic, altruistic, and greenwashing. Third, it would be a promising undertaking to perform a detailed analysis of banks' asset structures. In this way, we could further analyse the effect on the RD. Fourth, our study provides first exploratory insights into relevant determinates of the effects of CSR on bank risk. Further research should focus on the specific cause-effect relations between bank risk and the sub-components.

\section{Appendix}

See Fig. 2 and Tables 10, 11, 12, 13, 14 and 15.

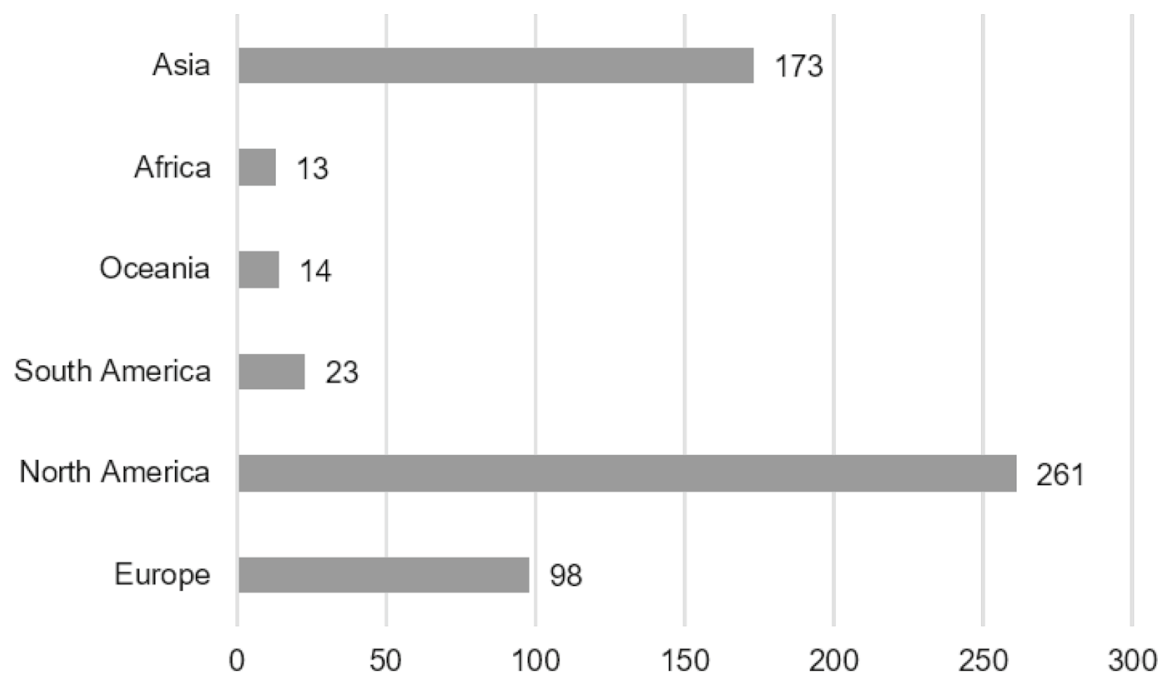

Fig. 2 The graph above provides information on the regional origin of the banks. Depicted are the absolute numbers of banks per continent. The total number of banks with available ESG scores in the sample is 582 
Table 10 Description of variables

\begin{tabular}{|c|c|}
\hline Variable & Description \\
\hline \multicolumn{2}{|l|}{ Panel A } \\
\hline z-score & $\begin{array}{l}\text { Measure of default risk. It is calculated as the sum of ROA and CAR over the } \\
5 \text { year standard deviation of ROA }\end{array}$ \\
\hline RD & $\begin{array}{l}\text { Measure of portfolio risk. It is calculated as risk-weighted assets over total assets } \\
\text { and measures the risk on the balance sheet }\end{array}$ \\
\hline \multicolumn{2}{|l|}{ Panel B } \\
\hline ESG score & $\begin{array}{l}\text { Measure of the overall corporate social responsibility. It is calculated as weighted } \\
\text { average of the Environmental score, Social score, and Governance score }\end{array}$ \\
\hline Environmental score & $\begin{array}{l}\text { Measure of company's environmental performance that indicates the impact on } \\
\text { natural systems }\end{array}$ \\
\hline Social score & $\begin{array}{l}\text { Measure of company's social performance about the confidence with employees, } \\
\text { customers and society }\end{array}$ \\
\hline Governance score & $\begin{array}{l}\text { Measure of company's governance practice that indicates the systems and } \\
\text { processes installed to guarantee that the management acts in the interests of } \\
\text { stakeholders }\end{array}$ \\
\hline Emissions & Measures company's emission efficiency in the context of its business activities \\
\hline Env. Innovation & $\begin{array}{l}\text { Reflects company's commitment to sustainability e.g. by offering an innovative } \\
\text { sustainable product portfolio }\end{array}$ \\
\hline Resource Use & Reflects company's eco-efficiency in terms of materials, energy or water \\
\hline Community & $\begin{array}{l}\text { Reflects company's social responsibility activities and it's business ethics commit- } \\
\text { ment }\end{array}$ \\
\hline Human Rights & Reflects compliance with human rights conventions by the company \\
\hline Product Responsibility & Reflects the quality and reliability of the offered products \\
\hline Workforce & $\begin{array}{l}\text { Reflects on the one hand the working conditions in the company and on the other } \\
\text { the offered development opportunities }\end{array}$ \\
\hline CSR-strategy & Reflects company's the adoption, application, and reporting of the CSR-strategy \\
\hline Management & Reflects management's compliance within the corporate governance guidelines \\
\hline Shareholders & Reflects the handling of shareholders and the prevention of takeovers \\
\hline \multicolumn{2}{|l|}{ Panel C } \\
\hline $\operatorname{logFTE}$ & Company size is approximated by the natural logarithm of full-time employees \\
\hline LR & $\begin{array}{l}\text { Capital structure is considered as the ratio of total liabilities over total equity, i.e. } \\
\text { the leverage ratio }\end{array}$ \\
\hline LoanRatio & $\begin{array}{l}\text { Business model indicator which measures the loan exposures as total gross loans } \\
\text { over total assets }\end{array}$ \\
\hline DepRatio & $\begin{array}{l}\text { Business model indicators which measures the deposits exposures as total deposits } \\
\text { over total assets }\end{array}$ \\
\hline ROE & $\begin{array}{l}\text { Return on equity measures profitability. It is calculated as net income before taxes } \\
\text { over total equity }\end{array}$ \\
\hline \multicolumn{2}{|l|}{ Panel D } \\
\hline Inflation & $\begin{array}{l}\text { Rate of price change in the whole economy. Measured by annual growth rate of } \\
\text { GDP implicit deflator. Source: Worldbank }\end{array}$ \\
\hline $\mathrm{GDP}_{\mathrm{Cap}}$ & Gross domestic product divided by midyear population. Source: Worldbank \\
\hline $\mathrm{GDP}_{\mathrm{Cap}}^{\text {Growth }}$ & Annual growth rate of GDP per capita. Source: Worldbank \\
\hline
\end{tabular}

The table gives short descriptions of the variables used in this study. Panel A comprises the risk measures, Panel B comprises the ESG data, Panel C comprises the bank specific control variables, and Panel D comprises the country specific control variables 
Table 11 Correlation metrics

\begin{tabular}{lllllll}
\hline & z-score & RD & ESG score & EnvPillar & SocPillar & GovPillar \\
\hline z-score & 1.00 & & & & & \\
RD & -0.01 & 1.00 & & & & \\
ESG score & -0.11 & -0.29 & 1.00 & & & \\
EnvPillar & -0.13 & -0.33 & 0.88 & 1.00 & 1.00 & 0.72 \\
SocPillar & -0.12 & -0.23 & 0.88 & 0.42 & 0.44 & 1.00 \\
GovPillar & -0.03 & -0.14 & 0.72 & & & \\
\hline
\end{tabular}

The table shows pairwise correlation coefficients of the risk measures, the ESG score, and its pillars

Table 12 Robustness: Winsorisation level (Multivariate robust FE regressions of risk on the ESG score)

\begin{tabular}{|c|c|c|c|c|c|c|}
\hline & (1) & (2) & (3) & (4) & (5) & (6) \\
\hline & Z-score & Z-score & Z-score & RD & RD & $\mathrm{RD}$ \\
\hline & Coef./se & Coef./se & Coef./se & Coef./se & Coef./se & Coef./se \\
\hline L.ESG score & $\begin{array}{l}1.2470^{* * *} \\
(0.12)\end{array}$ & $\begin{array}{l}0.9437 * * * \\
(0.13)\end{array}$ & $\begin{array}{l}0.7554 * * * \\
(0.15)\end{array}$ & $\begin{array}{l}-0.3249 * * * \\
(0.10)\end{array}$ & $\begin{array}{l}-0.1711 * * \\
(0.08)\end{array}$ & $\begin{array}{l}-0.1977 * * \\
(0.08)\end{array}$ \\
\hline L. $\log \mathrm{FTE}$ & & $\begin{array}{l}-13.3226^{*} \\
(7.81)\end{array}$ & $\begin{array}{l}-10.5866 \\
(7.79)\end{array}$ & & $\begin{array}{l}14.1429 \\
(10.95)\end{array}$ & $\begin{array}{l}15.5211 \\
(10.82)\end{array}$ \\
\hline L.LR & & $\begin{array}{l}0.0000 \\
(0.00)\end{array}$ & $\begin{array}{l}0.0000 * \\
(0.00)\end{array}$ & & $\begin{array}{l}0.0000 \\
(0.00)\end{array}$ & $\begin{array}{l}0.0000 \\
(0.00)\end{array}$ \\
\hline L.LoanRatio & & $\begin{array}{l}0.2007 \\
(0.18)\end{array}$ & $\begin{array}{l}0.1580 \\
(0.21)\end{array}$ & & $\begin{array}{l}-0.2862 * \\
(0.17)\end{array}$ & $\begin{array}{l}-0.2791 * \\
(0.15)\end{array}$ \\
\hline L.DepRatio & & $\begin{array}{l}1.5239 * * * \\
(0.25)\end{array}$ & $\begin{array}{l}1.3797 * * * \\
(0.25)\end{array}$ & & $\begin{array}{l}-0.6572 * * * \\
(0.13)\end{array}$ & $\begin{array}{l}-0.6790 * * * \\
(0.13)\end{array}$ \\
\hline L.ROE & & $\begin{array}{l}0.2869 * * \\
(0.13)\end{array}$ & $\begin{array}{l}0.2178 * * \\
(0.10)\end{array}$ & & $\begin{array}{l}0.1798 \\
(0.14)\end{array}$ & $\begin{array}{l}0.1603 \\
(0.13)\end{array}$ \\
\hline L.Inflation & & & $\begin{array}{l}0.9130 \\
(0.57)\end{array}$ & & & $\begin{array}{l}0.5084^{*} \\
(0.27)\end{array}$ \\
\hline L.GDP ${ }_{\text {Cap }}^{\text {Growth }}$ & & & $\begin{array}{l}2.4507 * * * \\
(0.52)\end{array}$ & & & $\begin{array}{l}0.4935^{*} \\
(0.29)\end{array}$ \\
\hline L.GDP ${ }_{\text {Cap }}$ & & & $\begin{array}{l}0.0034 * * \\
(0.00)\end{array}$ & & & $\begin{array}{l}0.0004 \\
(0.00)\end{array}$ \\
\hline Constant & $\begin{array}{l}-6.5554 \\
(6.19)\end{array}$ & $\begin{array}{l}-6.1129 \\
(67.25)\end{array}$ & $\begin{array}{l}-135.8365^{*} \\
(75.47)\end{array}$ & $\begin{array}{l}101.7768 * * * \\
(5.49)\end{array}$ & $\begin{array}{l}36.8341 \\
(95.11)\end{array}$ & $\begin{array}{l}12.04271 \\
(94.01)\end{array}$ \\
\hline $\mathrm{N}$ & 3949 & 3200 & 3117 & 2904 & 2674 & 2635 \\
\hline $\mathbf{R}_{a d j}^{2}$ & 0.03863 & 0.1217 & 0.1485 & 0.01910 & 0.1321 & 0.1381 \\
\hline
\end{tabular}

The table shows the coefficients and standard errors (in parenthesis) of multivariate robust FE regressions. The dependent variables are the bank risk measures $\mathrm{z}$-score and RD. The independent variables are the ESG score and bank and country specific control variables. The independent variables are 1 year lagged. Significance is denoted at the $10 \%\left(^{*}\right), 5 \%\left({ }^{* *}\right)$, and $1 \%\left({ }^{* *}\right)$ significance level. Data is winsorised at the 5 th and the 95 th percentile 
Table 13 Robustness: Winsorisation level (Multivariate robust FE regressions of risk on the environmental score)

\begin{tabular}{|c|c|c|c|c|c|c|}
\hline & (1) & (2) & (3) & (4) & (5) & (6) \\
\hline & z-score & z-score & z-score & $\mathrm{RD}$ & $\mathrm{RD}$ & $\mathrm{RD}$ \\
\hline & Coef./se & Coef./se & Coef./se & Coef./se & Coef./se & Coef./se \\
\hline L.EnvPillar & $\begin{array}{l}0.8414 * * * \\
(0.09)\end{array}$ & $\begin{array}{l}0.6674 * * * \\
(0.09)\end{array}$ & $\begin{array}{l}0.5480^{* * * *} \\
(0.10)\end{array}$ & $\begin{array}{l}-0.2973 * * * \\
(0.07)\end{array}$ & $\begin{array}{l}-0.2166^{* * *} \\
(0.05)\end{array}$ & $\begin{array}{l}-0.2390 \text { *** } \\
(0.05)\end{array}$ \\
\hline L. $\log$ FTE & & $\begin{array}{l}-13.1616^{*} \\
(7.61)\end{array}$ & $\begin{array}{l}-10.8003 \\
(7.58)\end{array}$ & & $\begin{array}{l}15.5576 \\
(11.00)\end{array}$ & $\begin{array}{l}16.9864 \\
(10.90)\end{array}$ \\
\hline L.LR & & $\begin{array}{l}0.0000 \\
(0.00)\end{array}$ & $\begin{array}{l}0.0000 \\
(0.00)\end{array}$ & & $\begin{array}{l}0.0000 \\
(0.00)\end{array}$ & $\begin{array}{l}0.0000 \\
(0.00)\end{array}$ \\
\hline L.LoanRatio & & $\begin{array}{l}0.1798 \\
(0.18)\end{array}$ & $\begin{array}{l}0.1303 \\
(0.21)\end{array}$ & & $\begin{array}{l}-0.2520 \\
(0.17)\end{array}$ & $\begin{array}{l}-0.2475 \\
(0.15)\end{array}$ \\
\hline L.DepRatio & & $\begin{array}{l}1.5579 * * * \\
(0.25)\end{array}$ & $\begin{array}{l}1.4059^{* * * *} \\
(0.25)\end{array}$ & & $\begin{array}{l}-0.6669 * * * \\
(0.13)\end{array}$ & $\begin{array}{l}-0.6930 \text { *** } \\
(0.13)\end{array}$ \\
\hline L.ROE & & $\begin{array}{l}0.2916^{* * *} \\
(0.13)\end{array}$ & $\begin{array}{l}0.2241^{* *} \\
(0.10)\end{array}$ & & $\begin{array}{l}0.1648 \\
(0.14)\end{array}$ & $\begin{array}{l}0.14435 \\
(0.12)\end{array}$ \\
\hline L.Inflation & & & $\begin{array}{l}0.8935 \\
(0.58)\end{array}$ & & & $\begin{array}{l}0.45077^{*} \\
(0.26)\end{array}$ \\
\hline L.GDP ${ }_{\text {Cap }}^{\text {Growth }}$ & & & $\begin{array}{l}2.3539 * * * \\
(0.53)\end{array}$ & & & $\begin{array}{l}0.5154 * \\
(0.29)\end{array}$ \\
\hline L.GDP ${ }_{\text {Cap }}$ & & & $\begin{array}{l}0.0035^{* * *} \\
(0.00)\end{array}$ & & & $\begin{array}{l}0.0005 \\
(0.00)\end{array}$ \\
\hline Constant & $\begin{array}{l}13.8755 * * * \\
(4.61)\end{array}$ & $\begin{array}{l}5.1654 \\
(66.73)\end{array}$ & $\begin{array}{l}-126.9003^{*} \\
(74.30)\end{array}$ & $\begin{array}{l}100.534 * * * \\
(3.67)\end{array}$ & $\begin{array}{l}25.1409 \\
(95.61)\end{array}$ & $\begin{array}{l}-2.3088 \\
(94.68)\end{array}$ \\
\hline $\mathrm{N}$ & 3949 & 3200 & 3117 & 2904 & 2674 & 2635 \\
\hline $\mathbf{R}_{a d j}^{2}$ & 0.0356 & 0.1220 & 0.1498 & 0.0326 & 0.1418 & 0.1486 \\
\hline
\end{tabular}

The table shows the coefficients and standard errors (in parenthesis) of multivariate robust FE regressions. The dependent variables are the bank risk measures $\mathrm{z}$-score and RD. The independent variables are the ESG environment pillar score and bank and country specific control variables. The independent variables are 1 year lagged. Significance is denoted at the $10 \%\left(^{*}\right), 5 \%\left(^{* *}\right)$, and $1 \%\left(^{* * *}\right)$ significance level. Data is winsorised at the 5 th and the 95 th percentile 
Table 14 Robustness: Winsorisation level (Multivariate robust FE regressions of risk on the social score)

\begin{tabular}{|c|c|c|c|c|c|c|}
\hline & (1) & (2) & (3) & (4) & (5) & (6) \\
\hline & Z-score & Z-score & Z-score & $\mathrm{RD}$ & RD & $\mathrm{RD}$ \\
\hline & Coef./se & Coef./se & Coef./se & Coef./se & Coef./se & Coef./se \\
\hline \multirow[t]{2}{*}{ L.SocPillar } & $0.8381 * * *$ & $0.5875^{* * *} *$ & $0.4035 * * *$ & $-0.1452 *$ & -0.0340 & -0.0504 \\
\hline & $(0.10)$ & $(0.11)$ & $(0.12)$ & $(0.08)$ & $(0.06)$ & $(0.06)$ \\
\hline \multirow[t]{2}{*}{ L.logFTE } & & -10.0831 & -7.3860 & & 12.7165 & 13.9480 \\
\hline & & $(8.00)$ & (7.96) & & (10.93) & (10.78) \\
\hline \multirow[t]{2}{*}{ L.LR } & & 0.0000 & 0.0000 & & 0.0000 & 0.0000 \\
\hline & & $(0.00)$ & $(0.00)$ & & $(0.00)$ & $(0.00)$ \\
\hline \multirow[t]{2}{*}{ L.LoanRatio } & & 0.2696 & 0.2013 & & $-0.3070^{*}$ & $-0.2920^{*}$ \\
\hline & & $(0.19)$ & $(0.22)$ & & $(0.17)$ & $(0.15)$ \\
\hline \multirow[t]{2}{*}{ L.DepRatio } & & $1.5414 * * *$ & $1.3856 * * *$ & & $-0.6658 * * *$ & $-0.6853 * * *$ \\
\hline & & $(0.25)$ & $(0.25)$ & & $(0.13)$ & $(0.13)$ \\
\hline \multirow[t]{2}{*}{ L.ROE } & & $0.2699 * *$ & $0.2023 * *$ & & 0.1861 & 0.1663 \\
\hline & & $(0.12)$ & $(0.09)$ & & $(0.15)$ & $(0.14)$ \\
\hline \multirow[t]{2}{*}{ L.Inflation } & & & 0.6410 & & & $0.5933 * *$ \\
\hline & & & $(0.56)$ & & & $(0.27)$ \\
\hline \multirow[t]{2}{*}{ L.GDP ${ }_{\text {Cap }}^{\text {Growth }}$} & & & $2.3818^{* * *}$ & & & $0.5064^{*}$ \\
\hline & & & $(0.53)$ & & & $(0.29)$ \\
\hline \multirow[t]{2}{*}{ L.GDP $_{\text {Cap }}$} & & & $0.0037 * *$ & & & 0.0002 \\
\hline & & & $(0.00)$ & & & $(0.00)$ \\
\hline \multirow[t]{2}{*}{ Constant } & $14.5633^{* * *}$ & -22.9463 & $-160.6256^{* *}$ & $92.3738 * * *$ & 44.9294 & 24.7033 \\
\hline & $(4.93)$ & $(69.05)$ & $(77.25)$ & $(4.20)$ & $(94.87)$ & $(93.62)$ \\
\hline $\mathrm{N}$ & 3949 & 3200 & 3117 & 2904 & 2674 & 2635 \\
\hline $\mathbf{R}_{a d j}^{2}$ & 0.0242 & 0.1113 & 0.1408 & 0.0047 & 0.1281 & 0.1333 \\
\hline
\end{tabular}

The table shows the coefficients and standard errors (in parenthesis) of multivariate robust FE regressions. The dependent variables are the bank risk measures $\mathrm{z}$-score and RD. The independent variables are the ESG social pillar score and bank and country specific control variables. The independent variables are 1 year lagged. Significance is denoted at the $10 \%\left({ }^{*}\right), 5 \%\left({ }^{* *}\right)$, and $1 \%\left(^{* *}\right)$ significance level. Data is winsorised at the 5th and the 95 th percentile 
Table 15 Robustness: Winsorisation level (Multivariate robust FE regressions of risk on the governance score)

\begin{tabular}{|c|c|c|c|c|c|c|}
\hline & (1) & (2) & $\begin{array}{l}\text { (3) } \\
\text { z-score }\end{array}$ & $\begin{array}{l}\text { (4) } \\
\text { RD }\end{array}$ & $\begin{array}{l}\text { (5) } \\
\text { RD }\end{array}$ & $\begin{array}{l}(6) \\
R D\end{array}$ \\
\hline & Coef./se & Coef./se & Coef./se & Coef./se & Coef./se & Coef./se \\
\hline L.GovPillar & $\begin{array}{l}0.4429 * * * \\
(0.08)\end{array}$ & $\begin{array}{l}0.2986^{* * * *} \\
(0.08)\end{array}$ & $\begin{array}{l}0.2331 \text { *** } \\
(0.08)\end{array}$ & $\begin{array}{l}-0.0948 \\
(0.07)\end{array}$ & $\begin{array}{l}-0.0046 \\
(0.06)\end{array}$ & $\begin{array}{l}-0.0067 \\
(0.07)\end{array}$ \\
\hline L. $\log \mathrm{FTE}$ & & $\begin{array}{l}-3.8763 \\
(8.01)\end{array}$ & $\begin{array}{l}-3.5309 \\
(7.85)\end{array}$ & & $\begin{array}{l}12.2327 \\
(10.83)\end{array}$ & $\begin{array}{l}13.3483 \\
(10.70)\end{array}$ \\
\hline L.LR & & $\begin{array}{l}0.0000 \\
(0.00)\end{array}$ & $\begin{array}{l}0.0000 \\
(0.00)\end{array}$ & & $\begin{array}{l}0.0000 \\
(0.00)\end{array}$ & $\begin{array}{l}0.0000 \\
(0.00)\end{array}$ \\
\hline L.LoanRatio & & $\begin{array}{l}0.3397^{*} \\
(0.19)\end{array}$ & $\begin{array}{l}0.2430 \\
(0.22)\end{array}$ & & $\begin{array}{l}-0.3129^{*} \\
(0.17)\end{array}$ & $\begin{array}{l}-0.2971^{*} \\
(0.15)\end{array}$ \\
\hline L.DepRatio & & $\begin{array}{l}1.5292 * * * \\
(0.25)\end{array}$ & $\begin{array}{l}1.3678^{* * *} \\
(0.25)\end{array}$ & & $\begin{array}{l}-0.6648 * * * \\
(0.13)\end{array}$ & $\begin{array}{l}-0.6828^{* * *} \\
(0.13)\end{array}$ \\
\hline L.ROE & & $\begin{array}{l}0.2328^{* *} \\
(0.10)\end{array}$ & $\begin{array}{l}0.1768^{* *} \\
(0.08)\end{array}$ & & $\begin{array}{l}0.1885 \\
(0.15)\end{array}$ & $\begin{array}{l}0.1694 \\
(0.14)\end{array}$ \\
\hline L.Inflation & & & $\begin{array}{l}0.5368 \\
(0.57)\end{array}$ & & & $\begin{array}{l}0.6159 * * \\
(0.27)\end{array}$ \\
\hline L.GDP & & & $\begin{array}{l}2.4503 * * * \\
(0.54)\end{array}$ & & & $\begin{array}{l}0.4994 * \\
(0.29)\end{array}$ \\
\hline L.GDP $_{\text {Cap }}$ & & & $\begin{array}{l}0.0039^{* *} \\
(0.00)\end{array}$ & & & $\begin{array}{l}0.0002 \\
(0.00)\end{array}$ \\
\hline Constant & $\begin{array}{l}34.5381 * * * \\
(4.20)\end{array}$ & $\begin{array}{l}-67.3896 \\
(70.68)\end{array}$ & $\begin{array}{l}-192.8314^{* * * *} \\
(74.38)\end{array}$ & $\begin{array}{l}89.5592 * * * \\
(3.72)\end{array}$ & $\begin{array}{l}47.7339 \\
(94.54)\end{array}$ & $\begin{array}{l}29.0979 \\
(93.01)\end{array}$ \\
\hline $\mathrm{N}$ & 3949 & 3200 & 3117 & 2904 & 2674 & 2635 \\
\hline $\mathbf{R}_{a d j}^{2}$ & 0.0090 & 0.1040 & 0.1384 & 0.0027 & .1278047 & 0.1328 \\
\hline
\end{tabular}

The table shows the coefficients and standard errors (in parenthesis) of multivariate robust FE regressions. The dependent variables are the bank risk measures z-score and RD. The independent variables are the ESG governance pillar score and bank and country specific control variables. The independent variables are 1 year lagged. Significance is denoted at the $10 \%\left({ }^{*}\right), 5 \%\left({ }^{* *}\right)$, and $1 \%\left({ }^{* * *}\right)$ significance level. Data is winsorised at the 5th and the 95th percentile

Acknowledgements This article has been awarded with the Best Paper Award at the Annual Event of Finance Research Letters (Puerto Vallarta, 2020). For helpful comments, we thank two anonymous reviewers, Thomas Hartmann-Wendels, Ann-Christine Brunen, Tjark Eschenroeder, Arndt-Gerrit Kund, Michael Torben Menk, and the discussants at the 7th Annual Conference on Risk Governance (Siegen, 2019) and the Annual Event of Finance Research Letters (Puerto Vallarta, 2020)

Funding Open Access funding enabled and organized by Projekt DEAL.

Data availability Not applicable.

Code availability Not applicable. 


\section{Declarations}

Conflict of interest There are no competing interests to declare.

Open Access This article is licensed under a Creative Commons Attribution 4.0 International License, which permits use, sharing, adaptation, distribution and reproduction in any medium or format, as long as you give appropriate credit to the original author(s) and the source, provide a link to the Creative Commons licence, and indicate if changes were made. The images or other third party material in this article are included in the article's Creative Commons licence, unless indicated otherwise in a credit line to the material. If material is not included in the article's Creative Commons licence and your intended use is not permitted by statutory regulation or exceeds the permitted use, you will need to obtain permission directly from the copyright holder. To view a copy of this licence, visit http://creativecommons.org/licen ses/by/4.0/.

\section{References}

Albuquerque R, Koskinen Y, Zhang C (2018) Corporate social responsibility and firm risk: theory and empirical evidence. Manag Sci 65(10):4451-4469

Ayadi R, De Groen W, Sassi I, Mathlouthi W, Rey H, Aubry O (2016) Banking business models monitor 2015 Europe. Available at SSRN 2784334

BaFin (2020) Guidance notice on dealing with sustainability risks

Bank of England (2018) Transition in thinking: the impact of climate change on the UK banking sector

Barth JR, Caprio G, Levine R (2008) Rethinking bank regulation: till angels govern. Cambridge University Press, Cambridge

Baule R, Tallau C (2016) Revisiting Basel risk weights: cross-sectional risk sensitivity and cyclicality. J Bus Econ 86(8):905-931

Bayazitova D, Shivdasani A (2012) Assessing TARP. Rev Financ Stud 25(2):377-407

Beck T, Levine R (2004) Stock markets, banks, and growth: panel evidence. J Bank Finance 28(3):423-442

Bikker JA, Haaf K (2002) Measures of competition and concentration in the banking industry: a review of the literature. Econ Financ Model 9(2):53-98

Bouslah K, Kryzanowski L, M'Zali B (2013) The impact of the dimensions of social performance on firm risk. J Bank Finance 37(4):1258-1273

Bouslah K, Kryzanowski L, M'Zali B (2018) Social performance and firm risk: impact of the financial crisis. J Bus Ethics 149(3):643-669

Boyd JH, Graham SL, Hewitt RS (1993) Bank holding company mergers with nonbank financial firms: effects on the risk of failure. J Bank Finance 17(1):43-63

BusinessWire (2012) JPMorgan Chase Offers Relief Following Hurricane Sandy. https://www.businesswi re.com/news/home/20121101006246/en/JPMorgan-Chase-Offers-Relief-Hurricane-Sandy. Last accessed 18 Feb 2020

Chen N, Huang H-H, Lin C-H (2018) Equator principles and bank liquidity. Int Rev Econ Finance 55(C):185-202

Chollet P, Sandwidi BW (2018) CSR engagement and financial risk: a virtuous circle? International evidence. Glob Finance J 38:65-81

Cornett MM, Erhemjamts O, Tehranian H (2016) Greed or good deeds: an examination of the relation between corporate social responsibility and the financial performance of us commercial banks around the financial crisis. J Bank Finance 70:137-159

Cui J, Jo H, Na H (2018) Does corporate social responsibility affect information asymmetry? J Bus Ethics 148(3):549-572

Demirgüç-Kunt A, Levine R (1999) Bank-based and market-based financial systems: cross-country comparisons. The World Bank, Washington

EBA (2019) EBA action plan on sustainable finance

EBA (2020) EBA discussion paper on management and supervision of ESG risks for credit institutions and investment firms 
Esteban-Sanchez P, de la Cuesta-Gonzalez M, Paredes-Gazquez JD (2017) Corporate social performance and its relation with corporate financial performance: international evidence in the banking industry. J Clean Prod 162:1102-1110

European Commission (2018) Action plan: financing sustainable growth

Feldman SJ, Soyka PA, Ameer PG (1997) Does improving a firm's environmental management system and environmental performance result in a higher stock price? J Investig 6(4):87-97

Finger M, Gavious I, Manos R (2018) Environmental risk management and financial performance in the banking industry: a cross-country comparison. J Int Financ Mark Inst Money 52:240-261

Fouquau J, Spieser PK (2015) Statistical evidence about LIBOR manipulation: a "Sherlock Holmes" investigation. J Bank Finance 50:632-643

Friede G, Busch T, Bassen A (2015) ESG and financial performance: aggregated evidence from more than 2000 empirical studies. J Sustain Finance Invest 5(4):210-233

Froot KA (1989) Consistent covariance matrix estimation with cross-sectional dependence and heteroskedasticity in financial data. J Financ Quant Anal 24(3):333-355

Gangi F, Meles A, D’Angelo E, Daniele LM (2019) Sustainable development and corporate governance in the financial system: are environmentally friendly banks less risky? Corp Soc Respons Environ Manag 26(3):529-547

Girerd-Potin I, Jimenez-Garcès S, Louvet P (2014) Which dimensions of social responsibility concern financial investors? J Bus Ethics 121(4):559-576

Godfrey PC, Merrill CB, Hansen JM (2009) The relationship between corporate social responsibility and shareholder value: an empirical test of the risk management hypothesis. Strateg Manag J 30(4):425-445

Goyal P, Rahman Z, Kazmi A (2013) Corporate sustainability performance and firm performance research: literature review and future research agenda. Manag Decis 51(2):361-379

Gramlich D, Finster N (2013) Corporate sustainability and risk. J Bus Econ 83(6):631-664

Houston JF, Lin C, Lin P, Ma Y (2010) Creditor rights, information sharing, and bank risk taking. J Financ Econ 96(3):485-512

Hryckiewicz A (2014) What do we know about the impact of government interventions in the banking sector? An assessment of various bailout programs on bank behavior. J Bank Finance 46:246-265

Hurley R, Gong X, Waqar A (2014) Understanding the loss of trust in large banks. Int J Bank Mark 32(5):348-366

Iannotta G, Nocera G, Sironi A (2013) The impact of government ownership on bank risk. J Financ Intermed 22(2):152-176

Jo H, Na H (2012) Does CSR reduce firm risk? Evidence from controversial industry sectors. J Bus Ethics 110(4):441-456

John K, Litov L, Yeung B (2008) Corporate governance and risk-taking. J Finance 63(4):1679-1728

King RG, Levine R (1993) Finance and growth: Schumpeter might be right. Q J Econ 108(3):717-737

Köster H, Pelster M (2017) Financial penalties and bank performance. J Bank Finance 79:57-73

Laeven L, Levine R (2009) Bank governance, regulation and risk taking. J Financ Econ 93(2):259-275

Laeven L, Kane EJ, Demirgüç-Kunt A (2008) Deposit insurance around the world: issues of design and implementation. MIT Press, Cambridge

Le Leslé V, Avramova S (2012) Revisiting risk-weighted assets. IMF Working Paper 12/90

Levine R, Zervos S (1998) Stock markets, banks, and economic growth. Am Econ Rev 88(3):537-558

Luo X, Bhattacharya CB (2009) The debate over doing good: corporate social performance, strategic marketing levers, and firm-idiosyncratic risk. J Mark 73(6):198-213

Margolis JD, Elfenbein HA, Walsh JP (2007) Does it pay to be good? A meta-analysis and redirection of research on the relationship between corporate social and financial performance. Working paper. Harvard Business School, Harvard University, Boston

Marie Lauesen L (2013) CSR in the aftermath of the financial crisis. Soc Responsib J 9(4):641-663

McGuire JB, Sundgren A, Schneeweis T (1988) Corporate social responsibility and firm financial performance. Acad Manag J 31(4):854-872

Mies M, Menk MT (2019) Environmental and climate risk disclosure von Kreditinstituten: Empirische Evidenz der nichtfinanziellen Risikoberichterstattung europäischer Banken. Zeitschrift für Umweltpolitik Umweltrecht 42(4):405-444

Miralles-Quirós MM, Miralles-Quirós JL, Redondo-Hernández J (2019) The impact of environmental, social, and governance performance on stock prices: evidence from the banking industry. Corp Soc Responsib Environ Manag 26(6):1446-1456 
Nandy M, Lodh S (2012) Do banks value the eco-friendliness of firms in their corporate lending decision? Some empirical evidence. Int Rev Financ Anal 25:83-93

NGFS (2019) A call for action climate change as a source of financial risk

Nofsinger JR, Sulaeman J, Varma A (2019) Institutional investors and corporate social responsibility. J Corp Finance 58:700-725

Oikonomou I, Brooks C, Pavelin S (2012) The impact of corporate social performance on financial risk and utility: a longitudinal analysis. Financ Manag 41(2):483-515

Orlitzky M, Benjamin JD (2001) Corporate social performance and firm risk: a meta-analytic review. Bus Soc 40(4):369-396

Porta RL, Lopez-de Silanes F, Shleifer A, Vishny RW (1998) Law and finance. J Polit Econ 106(6):1113-1155

Rafeld H, Fritz-Morgenthal SG, Posch PN (2019) Whale watching on the trading floor: unravelling collusive rogue trading in banks. J Bus Ethics 165:633-657

Refinitiv (2021) Environmental, social and governance (ESG) scores from REFINITIV. https://www.refin itiv.com/content/dam/marketing/en_us/documents/methodology/refinitiv-esg-scores-methodology. pdf. Last accessed 12 Aug 2021

Sassen R, Hinze A-K, Hardeck I (2016) Impact of ESG factors on firm risk in Europe. J Bus Econ 86(8):867-904

Scholtens B, Dam L (2007) Banking on the equator. are banks that adopted the equator principles different from non-adopters? World Dev 35(8):1307-1328

Schulte M, Winkler A (2019) Drivers of solvency risk-are microfinance institutions different? J Bank Finance 106:403-426

Sharfman MP, Fernando CS (2008) Environmental risk management and the cost of capital. Strateg Manag J 29(6):569-592

Shen C-H, Wu M-W, Chen T-H, Fang H (2016) To engage or not to engage in corporate social responsibility: empirical evidence from global banking sector. Econ Model 55:207-225

Soana M-G (2011) The relationship between corporate social performance and corporate financial performance in the banking sector. J Bus Ethics 104(1):133-148

Srivastav A, Hagendorff J (2016) Corporate governance and bank risk-taking. Corp Gov 24(3):334-345

TCFD (2017) Final report: recommendations of the task force on climate-related financial disclosures

United Nations (2015) Paris Agreement

United Nations Industrial Development Organization (2020) What is CSR. https://www.unido.org/ourfocus/advancing-economic-competitiveness/competitive-trade-capacities-and-corporate-responsibi lity/corporate-social-responsibility-market-integration/what-csr. Last accessed 18 Feb 2020

Vishwanathan P, van Oosterhout HJ, Heugens PP, Duran P, Van Essen M (2019) Strategic CSR: a concept building meta-analysis. J Manag Stud

Wang Q, Dou J, Jia S (2016) A meta-analytic review of corporate social responsibility and corporate financial performance: the moderating effect of contextual factors. Bus Soc 55(8):1083-1121

Williams RL (2000) A note on robust variance estimation for cluster-correlated data. Biometrics 56(2):645-646

Wu M-W, Shen C-H (2013) Corporate social responsibility in the banking industry: motives and financial performance. J Bank Finance 37(9):3529-3547

Publisher's Note Springer Nature remains neutral with regard to jurisdictional claims in published maps and institutional affiliations. 